\title{
Carbon investment into mobilization of mineral and organic phosphorus by arbuscular mycorrhiza
}

\author{
Alberto Andrino $^{1}$ (D) $\cdot$ Georg Guggenberger ${ }^{1} \cdot$ Leopold Sauheitl $^{1} \cdot$ Stefan Burkart ${ }^{2} \cdot$ Jens Boy $^{1}$
}

Received: 9 April 2020 /Revised: 17 August 2020 / Accepted: 20 August 2020 / Published online: 1 September 2020

(C) The Author(s) 2020

\begin{abstract}
To overcome phosphorus (P) deficiency, about $80 \%$ of plant species establish symbiosis with arbuscular mycorrhizal fungi (AMF), which in return constitute a major sink of photosynthates. Information on whether plant carbon (C) allocation towards AMF increases with declining availability of the P source is limited. We offered orthophosphate (OP), apatite (AP), or phytic acid (PA) as the only P source available to arbuscular mycorrhiza (AM) (Solanum lycopersicum $x$ Rhizophagus irregularis) in a mesocosm experiment, where the fungi had exclusive access to each $\mathrm{P}$ source. After exposure, we determined $\mathrm{P}$ contents in the plant, related these to the overall $\mathrm{C}$ budget of the system, including the organic $\mathrm{C}(\mathrm{OC})$ contents, the respired $\mathrm{CO}_{2}$, the phospholipid fatty acid (PLFA) 16:1 1 5c (extraradical mycelium), and the neutral fatty acid (NLFA) 16:1 $105 \mathrm{c}$ (energy storage) at the fungal compartment. Arbuscular mycorrhizal (AM) plants incorporated P derived from the three P sources through the mycorrhizal pathway, but did this with differing C-P trading costs. The mobilization of PA and AP by the AM plant entailed larger mycelium infrastructure and significantly larger respiratory losses of $\mathrm{CO}_{2}$, in comparison with the utilization of the readily soluble OP. Our study thus suggests that AM plants invest larger $\mathrm{C}$ amounts into their fungal partners at lower $\mathrm{P}$ availability. This larger $\mathrm{C}$ flux to the $\mathrm{AM}$ fungi might also lead to larger soil organic $\mathrm{C}$ contents, in the course of forming larger $\mathrm{AM}$ biomass under P-limiting conditions.
\end{abstract}

Keywords Apatite $\cdot$ Organic phosphorus $\cdot$ Phytate $\cdot$ Inorganic phosphorus $\cdot$ Arbuscular mycorrhiza $\cdot$ PLFA 16:1 w5c $\cdot$ NLFA $16: 1 \omega 5 \mathrm{c} \cdot$ Photosynthesis $\cdot$ Stable carbon isotopes

\section{Introduction}

Phosphorus is the most limiting nutrient for plant growth after nitrogen $(\mathrm{N})$, especially in soils from tropical ecosystems, where secondary minerals immobilize P (Johnston et al. 2019). As a consequence, almost $80 \%$ of plant species establish symbiotic associations with arbuscular mycorrhizal fungi (AMF) (Smith and Read 2008). This symbiotic relationship, being several hundreds of million years old (Lambers et al.

Electronic supplementary material The online version of this article (https://doi.org/10.1007/s00374-020-01505-5) contains supplementary material, which is available to authorized users.

Alberto Andrino

andrino@ifbk.uni-hannover.de

1 Institute of Soil Science, Leibniz Universität Hannover, Herrenhäuser Straße 2, 30419 Hannover, Germany

2 Institute of Climate Smart Agriculture, Thünen-Institut, Bundesallee 65, 38116 Braunschweig, Germany
2009), explores a large volume of soil and does this at a lower cost as compared with roots. Such low-cost modes of P acquisition are expected to be favored by natural selection and during the assembly of plant communities by competition (Raven et al. 2018). One reason for the better cost to benefit ratio is that AMF hyphae represent the lower construction and maintenance costs for infrastructure (2-20- $\mu \mathrm{m}$ diameter), compared with root hairs (100-500- $\mu \mathrm{m}$ diameter) (Hodge 2017). The AMF are able to mobilize the otherwise poorly accessible phosphate ions beyond the $\mathrm{P}$ depletion zone (Osorio et al. 2017), and are responsible for nearly $80 \%$ of the plant P uptake (Douds and Johnson 2007).

Mycorrhizal benefits are greater under P-limiting soil conditions than in P-rich ones. In exchange for the $\mathrm{P}$ acquisition, AMF represent a major sink for recently fixed plant photosynthates (Nottingham et al. 2010), investing the host plant $C$ into the fungal growth, respiration, and biological maintenance (Jansa et al. 2011). Photosynthetic rates are often higher in mycorrhizal than in non-mycorrhizal plants (Augé et al. 2016), as a result of improved plant nutrition, especially of 
P, in mycorrhizal plants (Gavito et al. 2019). The AM plants allocate $4-20 \%$ of the total $C$ fixed into the AMF structures (Parniske 2008), and up to 5\% of net photosynthesis is lost by hyphal respiration (Moyano et al. 2007). AMF may also act as a gateway for direct delivery of recent plant photosynthates to the hyphospheric microbes within hours (Kaiser et al. 2015), exhibiting an intimate relationship and suggesting a synergistic cooperation (Zhang et al. 2016).

Plant $\mathrm{P}$ acquisition strategies require photoassimilates as energy form (Li et al. 2019). In this regard, Turner (2008) hypothesized that the different soil $\mathrm{P}$ forms can be placed along a gradient of increasing energy investment required for their acquisition, since insoluble organic form (e.g., phytic acid, PA) and P-containing primary minerals (e.g., apatite, AP) have comparatively high pre-processing costs, even at high concentrations, and these costs may steeply rise, as concentration declines (Raven et al. 2018).

Apatite is the most important primary mineral containing $\mathrm{P}$ (Nezat et al. 2008). It accounts for over $95 \%$ of all $P$ in the Earth's crust, thus playing a vital role in providing $\mathrm{P}$ to all ecosystems (Ptáček 2016). The AMF may tap into the crystalline structure of the AP through the exudation of acids and mobilizing the released P (Ness and Vlek 2000), but there is not a single report on the acquisition costs.

Organic P constitutes $20-80 \%$ of the total $\mathrm{P}$ in the soil, with PA representing $>50 \%$ of the organic $\mathrm{P}$ (Shen et al. 2011). Turner (2008) identified PA as the $P$ source most resistant to hydrolysis, and the metabolically most expensive source among the soil $\mathrm{P}$ compounds. In plants establishing an ectomycorrhizal association (ECM), C allocation into the extraradical hyphae increases proportionally at the absence of readily available $\mathrm{P}$ and/or under low $\mathrm{P}$ conditions (Smits et al. 2012); furthermore, ECM might play a critical role in the decomposition of organic $\mathrm{P}$, essential to meet host plant $P$ requirements and maintain the balance of soil labile P (Fan et al. 2018). We recently confirmed the ability of the cosmopolitan AMF $R$. irregularis DAOM 197198 to mobilize free PA and PA bound to the iron oxide goethite. Their mobilization proved to be the most expensive for the mycorrhized plant, in terms of $\mathrm{C}$ investment (Andrino et al. 2019). On the one hand, AMF may exudate their own acid phosphomonoesterase, to mineralize organic $\mathrm{P}$ forms and access $\mathrm{P}$ sources that non-mycorrhizal plants are unable to mobilize (Sato et al. 2015). On the other one, soil microbes may cooperate intimately with the AMF by providing inorganic $\mathrm{P}$ released by the decomposition of organic sources, in exchange for $\mathrm{C}$ exuded by the hyphae. But the mechanisms by which these exudates trigger the process of $\mathrm{P}$ mineralization in bacteria are still unknown (Zhang et al. 2018).

In the present study, we aim at identifying some factors controlling the interrelation of the energy investment (C) by the model tomato plant (Solanum lycopersicum L.) to mobilize the differently accessible P pools in the soil, by a cosmopolitan AMF such as $R$. irregularis. For that, we will employ the same dual-compartment system, where exclusively the AMF hyphae have access to the different $P$ sources in a fungal compartment (FC) as in the experiment of Andrino et al. (2019). In the present study, we will quantify the full C budget of the mycorrhizal symbiosis by measuring the respired $\mathrm{CO}_{2}$, total organic $\mathrm{C}$ accumulated, and fungal biomass at the FC, and assess the C-P stoichiometry to acquire $\mathrm{P}$ from primary minerals such as $\mathrm{AP}$, as opposed to the mobilization of free orthophosphate (OP) and PA. Furthermore, we will investigate the fate of the newly assimilated photosynthates in the plant-AMF-microbiota continuum, attempting to understand whether plant and fungus react in a coordinated manner, when mobilizing P sources with differing accessibility. We hypothesize that less accessible P sources, namely PA and $\mathrm{AP}$, will cause larger photoassimilate investments by the host plant and will result in differing trading costs per $\mathrm{P}$ unit in comparison with easily accessible $\mathrm{P}$ sources such OP.

\section{Material and methods}

To compare the acquisition costs of incorporating P from differently accessible sources through the mycorrhizal pathway, we conducted two experiments. Experiment 1 allowed us to test the ability of the AMF to mobilize $\mathrm{P}$ from the different sources offered at the FC during a time-course experiment over 112 days, but more importantly, to estimate whether there is a differentiated plant $\mathrm{C}$ investment into the AMF. Experiment 2 was carried out to compare the current acquisition costs in the form of recent photoassimilates using stable isotope ${ }^{13} \mathrm{C}$ at the specific time point elucidated in the experiment 1 . This was done only at treatments, where it was possible to quantify the incorporation of the different $\mathrm{P}$ sources.

\section{Experiment 1}

\section{Solanum lycopersicum L. inoculation with Rhizophagus irregularis DAOM 197198}

A system of one plant and one fungus was selected to test our hypotheses. One-one models are limited to tackle with the diversity of possible responses that a natural system can offer, while they are excellently suited for elucidating processes and understanding the underlying mechanisms developed by single AMF species (Zou et al. 2015). Tomato seeds var. Moneymaker (Volmary $\mathrm{GmbH}$, Münster, Germany) were surface-sterilized with $\mathrm{H}_{2} \mathrm{O}_{2}(5 \%, 10 \mathrm{~min})$, rinsed with sterile distilled water $(3 \times)$ and germinated on the surface of a moistened filter paper inside a petri dish $\left(3\right.$ days, $\left.27^{\circ} \mathrm{C}\right)$. The R. irregularis DAOM 197198 model organism (Daubois et al. 2016) was selected as mycorrhizal symbiont due to its 
ubiquitous occurrence and adaptation to agricultural practices (Köhl et al. 2016). The inoculum of the strain DAOM 197198 consisting of spores and root fragments (Symplanta $\mathrm{GmbH} \&$ Co. KG. Darmstadt, Germany) was reproduced in a trap plant culture (Brundrett et al. 1996). Germinated tomato seeds were transplanted into 75-ml pots QP96 (HerkuPlast Kubern GmbH, Ering, Germany) with 0.4 g containing 35-50 AMF propagules (roots, spores, hyphae) and 70-ml autoclaved and acid washed quartz sand, while non-mycorrhizal controls (M -) received $0.4 \mathrm{~g}$ of non-inoculated chopped roots. The quartz sand was used as plant and fungal growth substrate due to its suitability for the AM mycelium development (Olsson and Johansen 2000). Mycorrhizal and control plants were grown at a greenhouse for 4 weeks (photoperiod 16/8 h light/dark, temperature $24 / 20{ }^{\circ} \mathrm{C}$ light/dark, 50-60\% relative air humidity, photon flux density of $175-230 \mu \mathrm{mol} \mathrm{m} \mathrm{m}^{-2} \mathrm{~s}^{-1}$ ). Plants were watered every day with $10 \mathrm{ml}$ deionized water, and on alternate days the pots were fertilized with $5 \mathrm{ml}$ low $\mathrm{P}$ (0.32 mM) modified Long Ashton nutrient solution $\mathrm{pH} 6.5$ (Hewitt 1966). A quality control was carried out before the transplantation into the mesocosm, to monitor whether the AM plants were mycorrhized. For this, tomato mycorrhizal roots from AM plants and controls were stained using the ink and vinegar staining technique for visualizing the AMF colonization (Vierheilig et al. 1998). The percentage of mycorrhization was higher than $60 \%$ for plants transplanted into the mesocosms.

\section{Temporal dynamics}

Four-week-old mycorrhized tomato seedlings were planted into each mesocosm and placed at a greenhouse (photoperiod 16/8 h light/dark; temperature $24 / 20{ }^{\circ} \mathrm{C}$ light/dark; 50-60\% relative humidity; photon flux density of $175-$ $230 \mu \mathrm{mol} \mathrm{m} \mathrm{m}^{-2} \mathrm{~s}^{-1}$ ). Once a week, mesocosms were rotated within the greenhouse to achieve homogeneous growth conditions. To observe the temporal dynamics on the $\mathrm{P}$ acquisition by the AM plants and the controls, they were sampled five times within 112 days. The first sampling time was at the day of transplanting (day 0 ) to determine initial plant $\mathrm{P}$ content $(n=5)$, followed by four sampling times at days 35, 56, 86, and 112. At each sampling time, three biological replicates of each treatment were sampled.

The mesocosms consisted of a plant compartment (PC) and a FC, into which only the AMF hyphae were able to grow and mobilize the P sources offered there (Fig. 1a). Between both compartments, two barriers separated mycorrhizal roots and mycelium: a 20- $\mu \mathrm{m}$ pore size polyamide mesh (Franz Eckert GmbH, Waldkirch, Germany) (Watkins et al. 1996; Fitter et al. 1998) and a polytetrafluoroethylene (PTFE) membrane with a pore size of 5-10- $\mathrm{mm}$ (Pieper Filter GmbH, Bad Zwischenahn, Germany). AMF hyphae exhibit a high degree of plasticity in terms of its architecture (Püschel et al. 2020).
AM arterial hyphae are much finer than roots at 20-30 $\mu \mathrm{m}$, and their fine distal absorptive hyphae are only about $2-7-\mu \mathrm{m}$ in diameter according to Leake and Read (2017). The PTFE membrane allowed the AM hyphae to cross but did not allow mass flow and diffusion of ions to the PC; thus, sources were only accessible to the AM plant via the hyphae (Mäder et al. 1993).

\section{Phosphorus sources offered at the fungal compartment}

Three P sources were offered at the fungal compartment. Orthophosphate (OP) was used as inorganic and readily available source in the form of $\mathrm{KH}_{2} \mathrm{PO}_{4}$. Phytic acid (PA) (SigmaAldrich, Taufkirchen, Germany) was chosen as the organic source. A total content of $10 \mathrm{mg} \mathrm{P}$ was applied in the form of OP or PA and dissolved in $16 \mathrm{ml}$ autoclaved MilliQ water and mixed with $60 \mathrm{~g}$ autoclaved acid washed quartz sand placed inside each fungal compartment. Ten milligram $P$ content was decided on the basis to sustain the plant $\mathrm{P}$ necessities during the next 3 months after planting the seedlings into the mesocosms. As third P source, we have chosen AP as a primary mineral source (2-mm diameter) (Krantz Company, Bonn, Germany). An average P content of $18.72 \%$ within the AP was characterized using a field emission scanning electron microscope equipped with an energy-dispersive spectrometer (Phillips/FEI XL-30, Hillsboro, Oregon, USA). Easily available $\mathrm{P}$ in water was determined for the AP by shaking $1 \mathrm{~g}$ of the mineral with $30 \mathrm{ml}$ of autoclaved MilliQ water $\mathrm{pH} 7(n=3)$ in a $50-\mathrm{ml}$ falcon test tube. The tubes were placed on an orbital shaker at $250 \mathrm{rpm}$ for 7 days to determine maximum amount of $\mathrm{P}$ released from the AP in MilliQ water. The centrifuged supernatant $(3000 \times g, 15 \mathrm{~min})$ was filtered through a $0.45-\mu \mathrm{m}$ syringe filter (PVDF) and $1 \mathrm{ml}$ was mixed with $1 \mathrm{ml} \mathrm{30 \%} \mathrm{HNO}_{3}$, and the mixture was filled up to $10 \mathrm{ml}$ with MilliQ water. Total P concentration was measured by ICP-MS Agilent 7500C (Agilent Technologies Ireland Ltd., Cork, Ireland) and resulted in $0.03 \mathrm{mg} \pm 0.004 \mathrm{mg} \mathrm{P} \mathrm{g}^{-1} \mathrm{AP}$ in the MilliQ water. An amount of $3 \mathrm{~g}$ AP containing $562 \mathrm{mg}$ total $P$ and $0.09 \mathrm{mg}$ easily available $P$ was added to $60 \mathrm{~g}$ quartz sand and $16 \mathrm{ml}$ autoclaved MilliQ water. Apatite was added in a greater amount as compared with OP and PA, to know whether AMF could exclusively mobilize more $P$ than the easily available fraction. Apatites are mostly of sedimentary origin (Arif et al. 2017), and the different formation processes have an impact in their physical, chemical and crystallographic properties and consequently in their effectiveness as a $\mathrm{P}$ source (Arcand and Schneider 2006). For this reason, it was decided that AP should be in excess, thus preventing $\mathrm{P}$ from being a limiting nutrient since the water available fraction was already very low $(0.03 \mathrm{mg} \mathrm{P} / \mathrm{g} \mathrm{AP})$. Furthermore, the other two P sources OP and PA were homogeneously distributed throughout the $\mathrm{FC}$, having been dissolved in ultra-pure water, while 2-mm AP particles were mixed with the quartz sand. 
Fig. 1 Scheme of mesocosms containing an arbuscular mycorrhizal plant in the left compartment and a fungus in the right compartment, also containing one of the three different $\mathrm{P}$ forms: orthophosphate in solution as readily available $\mathrm{P}$ form, apatite as mineral P source, and hytate as organic $\mathrm{P}$ source or a blank with no P. The plant compartment is separated from the fungal compartment by a double-mesh system, so that only the mycelium is able to access to the different $P$ sources. (a) The fungal compartment of the mesocosms is connected to the EGM-4 infrared gas analyzer for $\mathrm{CO}_{2}$ measurement (experiment 1). (b) Scheme of the mesocosms setup used to measure the $\mathrm{CO}_{2}$ content and the $\delta^{13} \mathrm{CO}_{2}$ ratio respired at the fungal compartment. The gas bags were filled with the air respired from the fungal compartment and then were measured in the Picarro G1101-I (experiment 2). Abbreviations are OP, orthophosphate; AP, apatite; PA, phytic acid; M+, mycorrhizal plant with no $\mathrm{P}$
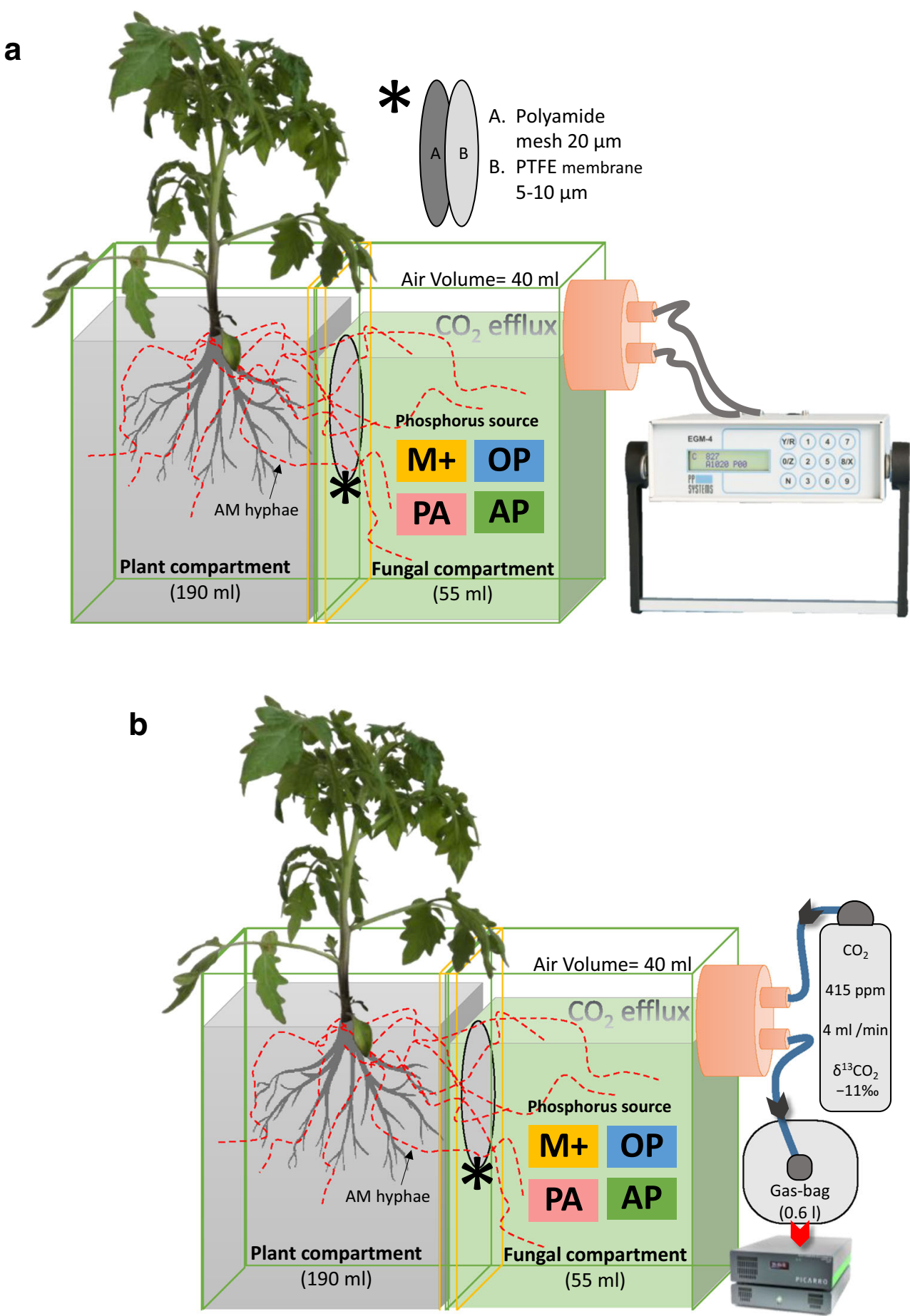

Thus, AP was also supplied in excess, to increase the probability of the hyphae exploiting the 2-mm granules mixed in the FC.

The water content at the fungal compartments was checked once a week and maintained with autoclaved MilliQ water at a volumetric water content of $19 \%$ (equivalent to field capacity) with the aid of a time-domain reflectometry probe Trime Pico connected to a Trime-FM version P2 (Imko Micromodultechnik $\mathrm{GmbH}$, Ettlingen, Germany).

\section{Plant $\mathrm{P}$ content}

At each of the five sampling times, shoots and roots were airdried $\left(70^{\circ} \mathrm{C}, 48 \mathrm{~h}\right.$ ), weighed, and ball-milled (Retsch $\mathrm{GmbH}$, Haan, Germany). An aliquot of the grinded shoot and root samples was incinerated at $480{ }^{\circ} \mathrm{C}$ for $8 \mathrm{~h}$, digested with $1 \mathrm{ml} \mathrm{30 \%} \mathrm{HNO}_{3}$, filtered through a $0.45-\mu \mathrm{m}$ syringe filter (PVDF) and analyzed by ICP-MS (Agilent 7500C, Agilent Technologies Ireland Ltd., Cork, Ireland). The amount of total 
P incorporated by the AM plant over time was calculated as the difference of the total $\mathrm{P}$ content at each sampling time and the average total $\mathrm{P}$ content initially present in the transplanted plants at day $0(n=5)$.

\section{Carbon dioxide production and organic $\mathrm{C}$ in the fungal compartment}

At each sampling time, $2 \mathrm{~g}$ from each fungal compartment were air-dried $\left(70{ }^{\circ} \mathrm{C}, 48 \mathrm{~h}\right)$, weighed, and ball-milled. The total $\mathrm{C}$ content was determined on an Elementar vario Isotope cube $\mathrm{C} / \mathrm{N}$ analyzer (Elementar $\mathrm{GmbH}$, Hanau, Germany) and was considered organic $\mathrm{C}(\mathrm{OC})$, as there was no inorganic $\mathrm{C}$ in the fungal compartment. For the calculation of the total OC in the fungal compartment, the total $\mathrm{C}$ content $\left(\mathrm{mg} \mathrm{g}^{-1}\right)$ was multiplied by the total weight of substrate in the fungal compartment. The $\mathrm{CO}_{2}$ production rate $\left(\mathrm{mmol} \mathrm{CO}_{2} \mathrm{~m}^{2} \mathrm{~h}^{-1}\right)$ was measured in the fungal compartment with an EGM-4 infrared gas analyzer (PP-systems, Hitchin, UK), a closed dynamic system (Vermue et al. 2008), during the whole experiment at 5 days per week (Fig. 1a). The cumulative $\mathrm{CO}_{2}-\mathrm{C}$ production was interpolated using a cubic spline function and calculated in milligram at each fungal compartment for each sampling day (Gentsch et al. 2018). The cumulative $\mathrm{CO}_{2}-\mathrm{C} / \mathrm{OC}$ ratio was used as a proxy of the metabolic activity at the fungal compartment (Eq. 1). In the case of those AM plants mobilizing PA, when calculating the $\mathrm{CO}_{2}-\mathrm{C}$ to $\mathrm{OC}$ ratio, $3.84 \mathrm{mg} \mathrm{C}$ was subtracted from the total $\mathrm{OC}$ found in the $\mathrm{FC}$, as that is the amount of $\mathrm{C}$ present in the $37.72 \mathrm{mg}$ of PA containing $10 \mathrm{mg}$ P.

$\mathrm{CO}_{2}-\mathrm{C} / \mathrm{OC}=\frac{\text { cumulative } \mathrm{CO}_{2}-\mathrm{C}(\mathrm{mg})}{\text { organic } \mathrm{C}(\mathrm{mg})}$

\section{R. irregularis: biomass and energy storage estimation}

The fatty acid composition of $R$. irregularis DAOM 197198 includes molecules from C16:0 to C22:2 with 16:1 105 as major fatty acid (Wewer et al. 2014). The PLFA $16: 1 \omega 5 \mathrm{c}$ is a biomarker to estimate the amount of extraradical AMF mycelia (Olsson and Johansen 2000). The NLFA 16:1 $105 \mathrm{c}$ biomarker estimates the amount of energy the fungus allocates for storage and is found in vesicles, spores, and extraradical mycelium (Bååth 2003). It is metabolized in the mycelium through the glyoxalate cycle providing the major fungal respiratory substrate (Van Aarle and Olsson 2003).

Lipids were extracted twice from $16 \mathrm{~g}$ of the different fungal compartments, belonging to different treatments and harvesting points, using a chloroform-methanol-citrate buffer $0.15 \mathrm{M} \mathrm{pH} 4$ (1:2:0.8 v:v:v). Extracts were fractionated by solid-phase extraction with activated silica gel (Sigma-Aldrich, pore size $60 \AA$, 70-230 mesh) into neutral lipid fatty acids (NLFA), glycolipids, and phospholipid fatty acids (PLFA) by elution with $5 \mathrm{ml}$ of chloroform, $20 \mathrm{ml}$ of acetone, and $20 \mathrm{ml}$ of methanol, respectively. The PLFA and NLFA samples were exposed to mild alkaline methanolysis. Transformation of phospholipids and neutral lipids into free fatty acid methyl esters (FAMEs) was based on Frostegård et al. (1991) with modifications by Bischoff et al. (2016). FAMEs were separated by gas chromatography using an Agilent 7890A GC system (Agilent Technologies Ireland Ltd., Cork, Ireland) equipped with a 60$\mathrm{m}$ Zebron capillary GC column $(0.25-\mathrm{mm}$ diameter and $0.25-\mu \mathrm{m}$ film thickness; Phenomenex, Torrance, California, USA) and quantified with a flame ionization detector, using $\mathrm{He}$ as carrier gas. Nonadecanoic acid $(25 \mu \mathrm{g})$ and glyceryl tridodecanoate $(25 \mu \mathrm{g})$ were used as internal standards during the extraction, and tridecanoic acid methyl ester $(15 \mu \mathrm{g})$ was added to each sample and standard before GC analysis as a recovery standard. For the fatty acid identification, the relative retention times were compared with that of the internal standard using the Agilent GC ChemStation (B.03.02.341) software. In our study, PLFA and NLFA 16:1 $1 \omega 5 \mathrm{c}$ were measured to estimate the biomass and energy storage of $R$. irregularis in the fungal compartment, respectively (Stumpe et al. 2005). Three ratios were calculated to evaluate the C-P trading costs between the $\mathrm{AMF}$ and the host plant to acquire the different $\mathrm{P}$ sources. The ratios between 16:1 w5c PLFA to plant $P$ uptake (Eq. 2) and NLFA to plant P uptake (Eq. 3) served to estimate the investment made by the tomato plants into their fungal partner in either biomass or energy storage to obtain $P$ from each source, respectively. The ratio between NLFA 16:1 $1 \omega 5 \mathrm{c}$ and PLFA 16:1 $1 \omega 5 \mathrm{c}$ (Eq. 4) was used as an index for the R. irregularis growth strategy of (Rinnan and Bååth 2009). A high NLFA 16:1cusc to PLFA $16: 1 \omega 5 \mathrm{c}$ ratio denotes $\mathrm{C}$ allocation to storage products in form of neutral lipids, in order to meet the catabolic needs of the fungus. Additionally, this ratio allows to discriminate between bacterial and fungal origin of the $16: 1 \omega 5 \mathrm{c}$ fatty acid. When the NLFA $16: 1 \omega 5 \mathrm{c}$ to PLFA $16: 1 \omega 5 \mathrm{c}$ was $>1$, the fatty acid originated from AM fungi and not from bacteria (Cozzolino et al. 2016).

PLFA $16: 1 \omega 5 \mathrm{c} / \mathrm{P}=\frac{\text { PLFA } 16: 1 \omega 5 \mathrm{c}(\text { total } \mu \mathrm{g} \text { per fungal compartment })}{\mathrm{P} \text { incorporated }(\mathrm{mg} \text { per plant })}$

NLFA $16: 1 \omega 5 \mathrm{c} / \mathrm{P}=\frac{\text { NLFA } 16: 1 \omega 5 \mathrm{c} \text { (total } \mu \mathrm{g} \text { per fungal compartment) }}{\mathrm{P} \text { incorporated }(\mathrm{mg} \text { per plant })}$

$\mathrm{NLFA} /$ PLFA $=\frac{\text { NLFA } 16: 1 \omega 5 \mathrm{c}(\text { total } \mu \mathrm{g} \text { per fungal compartment })}{\text { PLFA } 16: 1 \omega 5 \mathrm{c} \text { (total } \mu \mathrm{g} \text { per fungal compartment })}$ 


\section{Experiment 2}

The decision on the sampling day for experiment 2 was made on the basis of the results from experiment 1 . The ideal labeling point for experiment 2 was defined at the moment when all treatments showed the maximum $\mathrm{P}$ incorporation from the different $\mathrm{P}$ sources. The same growing conditions described in experiment 1 were replicated for two identical groups of plants, which were grown until the date determined at experiment 1 . The first group of plants was pulse-labeled with ${ }^{13} \mathrm{C}$ stable isotope and the second one was not labeled as control. Each identical group contained three biological replications for each P source and a mycorrhized control plant without P. The labeling experiment aimed at determining the amount of freshly assimilated $\mathrm{C}$ invested on the one hand, into leaves, shoots, roots, substrates of the plant compartment, and on the other one, into the respired $\mathrm{CO}_{2}$ and the different microbial communities at the fungal compartment.

\section{Photosynthetic rates}

The photosynthetic capacity of the tomato plants was measured with the LI-6400 (Licor, Lincoln, NE, USA) on recently fully expanded third or fourth leaves from top, 1 day before the ${ }^{13} \mathrm{CO}_{2}$ pulse labeling. The photosynthetic rate was used to test the effect of the different $P$ sources on the host's carbohydrate metabolism, as P deficiency may cause a rapid decrease in photosynthetic rates (Maathuis 2009). Values were recorded at $22^{\circ} \mathrm{C}$ in the leaf cuvette, a photon flux density of $1000 \mu \mathrm{mol} \mathrm{m} \mathrm{m}^{-2} \mathrm{~s}^{-1}$, approx. 50\% relative humidity, airflow rate of $400 \mu \mathrm{mol} \mathrm{s}{ }^{-1}$, an external $\mathrm{CO}_{2}$ concentration of $360 \mathrm{ppm}$, and the $\mathrm{CO}_{2}$ mixer to reference $400 \mathrm{ppm}$.

\section{${ }^{13} \mathrm{C}$ pulse labeling: ${ }^{13} \mathrm{C}$ incorporation into respired $\mathrm{CO}_{2}$, plant tissues, and substrates}

Mesocosms were placed into a phyto-chamber $\left(20-22^{\circ} \mathrm{C}, 50\right.$ $60 \%$ relative air humidity, photon flux density of $195 \mu \mathrm{mol} /$ $\mathrm{m} / \mathrm{s}$ ) and connected to a multi-valve system through a gas inlet and outlet at the fungal compartment to test for air leaks. Purified air with a $\mathrm{CO}_{2}$ concentration of $415 \mathrm{ppm}$ and a $\delta^{13} \mathrm{C}$ ratio of $-11 \%$ (Zero Air generator UHP-35ZA-S, Parker Hannifin, Cleveland, USA) was then pumped for $120 \mathrm{~min}$ through the fungal compartment $\left(4 \mathrm{ml} \mathrm{min}^{-1}\right)$, and the stability of the flow rate was checked every $10 \mathrm{~min}$. Once the absence of leaks in the gas circuit between the mesocosms and the valve system has been verified, 12 sampling bags (three bags per treatment) were connected to the programmable valve system and began filling for the next $120 \mathrm{~min}$ (Fig. $1 \mathrm{~b}$ and S2). After all bags were filled, they were measured sequentially at the Picarro G1101-I cavity ring-down spectrometer (Picarro Inc., Sunnyvale, USA) to determine the
${ }^{13} \mathrm{CO}_{2}$ abundance in the respired $\mathrm{CO}_{2}$ of each mesocosm. As these samples were taken before labeling, the corresponding values were defined as the background.

Thereafter, all mesocosms were brought to a labeling box $(60 \times 120 \times 50 \mathrm{~cm}, \mathrm{H} \times \mathrm{W} \times \mathrm{D})$ with forced ventilation (Fig. S2) to promote homogeneous ${ }^{13} \mathrm{CO}_{2}$ distribution during the pulse labeling. At the moment of closing the box, the internal $\mathrm{CO}_{2}$ concentration was $452 \mathrm{ppm}$ had a $\delta^{13} \mathrm{C}$ ratio of $-12.23 \%$. Another identical set of mesocosms was reserved to determine the natural abundances in the plant tissues and the substrates of both compartments during the course of the experiment. The labeling box was placed inside a greenhouse $\left(20{ }^{\circ} \mathrm{C}, 50-60 \%\right.$ relative air humidity, photon flux density of $\left.195 \mu \mathrm{mol} \mathrm{m}{ }^{-2} \mathrm{~s}^{-1}\right)$. The ${ }^{13} \mathrm{CO}_{2}$ tracer used for pulse labeling consisted of $2 \mathrm{~g} \mathrm{Ca}^{13} \mathrm{CO}_{3}$ (99 atom\% ${ }^{13} \mathrm{C}$ ) (Sigma-Aldrich, Steinheim, Germany). The labeling box was closed at 10:00 h, and the tracer was dissolved in $1 \mathrm{M} \mathrm{H}_{2} \mathrm{SO}_{4}$ injected through the wall of the chamber. At 12:00 h, the labeling was stopped by opening the box and moving the labeled mesocosms to another room.

The $\mathrm{CO}_{2}$ concentration and its ${ }^{13} \mathrm{C}$ signature in the fungal compartment was determined by a Picarro G1101-I (Picarro Inc., Sunnyvale, USA) (Fig. 1b and S2). To allow for a higher sampling intensity, a programmable valve system was developed to simultaneously collect a set of samples and then measure them consecutively. Gas samples were collected in 0.6-1 gas sampling bags Tedlar ${ }^{\circledR}$ PLV with Thermogreen ${ }^{\circledR}$ LB-2 Septa (Sigma-Aldrich, Steinheim, Germany). Different pretests were carried out to find out the optimum sample volume for the Picarro device to obtain a steady measurement. It was found that at least $300 \mathrm{ml}$ per bag were sufficient for a 10-min continuous measurement. The mesocosms were connected to the programmable valve system, and the airflow was adjusted to $4 \mathrm{ml} \mathrm{min}^{-1}$ for each of the 12 mesocosms. Once the airflow through each mesocosm was steady, the first batch of gas bags was connected from 13:00 to15:00 h (Fig. S2) as described for background sampling, followed by six other sampling times, covering a total of $25.5 \mathrm{~h}$ since the end of the ${ }^{13} \mathrm{CO}_{2}$ pulse labeling (Fig. S2).

Leaves, shoots, roots, plant, and fungal compartment substrates were sampled $27 \mathrm{~h}$ after the labeling finished. The samples were freeze-dried and ball-milled, and aliquots were weighed into tin capsules for isotope ratio mass spectrometry analysis. The content of total $\mathrm{C}$ and the $\delta^{13} \mathrm{C}$ ratio in the samples was determined with the elemental analyzer Isotope cube (Elementar GmbH, Hanau, Germany) connected to an Isoprime 100 isotope ratio mass spectrometer (Elementar $\mathrm{GmbH}$, Hanau, Germany) via a continuous flow inlet using helium (99.999\% purity; Linde, Munich, Germany) as carrier gas. Calibration was carried out with certified solid standards from the International Atomic Energy Agency (IAEA, Vienna, Austria) sucrose (IAEA-CH-6), cellulose (IAEA$\mathrm{CH}-3$ ), and caffeine (IAEA-600). The enrichment of ${ }^{13} \mathrm{C}$ 
was reported as atom $\%$ of ${ }^{13} \mathrm{C}\left(\right.$ at $\left.\%{ }^{13} \mathrm{C}\right)$, which was calculated with Eq. 5 for all plant, substrate, and gas samples,

$\mathrm{at} \% 13 \mathrm{C}=\frac{\left(100 \times \mathrm{AR} \times\left(\frac{\delta 13 \mathrm{C}}{1000+1}\right)\right)}{1+\left(\operatorname{AR} \times\left(\frac{\delta 13 \mathrm{C}}{1000+1}\right)\right)}$

where AR represents the absolute ratio of ${ }^{13} \mathrm{C}:{ }^{12} \mathrm{C}$ relative to the Vienna PeeDee Belemnite standard $(0.011182)$ and $\delta^{13} \mathrm{C}$ is the value in calibrated \%o (Slater et al. 2001).

The proportion of freshly assimilated $\mathrm{C}\left(\% \mathrm{C}_{\mathrm{F}}\right)$ in the different pools (plant tissues, substrates, and respired $\mathrm{CO}_{2}$ ) was calculated based on a two-pool mixing model as given in Eq. 6. Here, at $\%{ }^{13} \mathrm{C}$ is the ${ }^{13} \mathrm{C}$ enrichment in the labeled (L) or unlabeled (UL) treatment, or the tracer $(\mathrm{T})$, respectively.

$\% \mathrm{CF}=\left(\frac{\mathrm{at} \% 13 \mathrm{CL}-\mathrm{at} \% 13 \mathrm{CUL}}{\mathrm{at} \% 13 \mathrm{CT}-\mathrm{at} \% 13 \mathrm{CUL}}\right) \times 100$

To calculate the content of freshly assimilated $\mathrm{C}\left(\mathrm{C}_{\mathrm{F}}\right)$ in each sample (plant, substrate, gas), the $\% \mathrm{C}_{\mathrm{F}}$ (calculated with Eq. 6) was divided by 100 and the result was multiplied by the total $\mathrm{C}$ content of the labeled sample (L) (Eq. 7):

$\mathrm{CF}(\mathrm{mg}$ or $\mu \mathrm{g})=\left(\frac{\mathrm{at} \% 13 \mathrm{CF}}{100}\right) \times \mathrm{CL}$

All the freshly assimilated $\mathrm{C}$ contents (CF) were summed up, and the relative allocation of fresh $\mathrm{C}$ to the different pools (plant, substrate, gas) was calculated for each treatment.

\section{${ }^{13} \mathrm{C}$ PLFA and ${ }^{13} \mathrm{C}$ NLFA analysis}

Phospholipids and neutral lipids were extracted, saponified to the respective free fatty acids, and derivatized following the protocol described for experiment 1 . A set of external standards (multi-standard) consisting of 17 fatty acids belonging to different microbial groups (Table 1) and internal standards (SigmaAldrich, Taufkirchen, Germany) were derivatized and measured together with the PLFA and NLFA fungal compartment samples. The ${ }^{13} \mathrm{C}$ enrichment and the concentration in each FAME were measured in triplicate with an Agilent 7890A GC system (Agilent Technologies Ireland Ltd., Cork, Ireland) coupled with an Isoprime 100 IRMS (Elementar GmbH, Hanau, Germany) via a combustion interface and a continuous flow inlet using helium (99.999\% purity Linde, Germany) as gas carrier. The area below each chromatogram peak and the $\delta^{13} \mathrm{C}$ values of the 17 substances plus internal standards were processed with the IonOS 2.0 software (Isoprime, Elementar GmbH, Hanau, Germany) to calculate the concentrations and the at $\%{ }^{13} \mathrm{C}$. respectively, of the different PLFA and NLFA biomarkers within the multi-standard solution and the samples.

The corrected PLFA and NLFA $\delta^{13} \mathrm{C}$ values were calculated to at $\%{ }^{13} \mathrm{C}$ using Eq. 5. The proportion of freshly assimilated $\mathrm{C}$ into each PLFA or NLFA sample $\left(\% \mathrm{C}_{\mathrm{F}}\right.$ PLFA or $\% \mathrm{C}_{\mathrm{F} \text { NLFA }}$ ) was calculated using a two-pool mixing model explained in Eq. 6. To calculate the content of freshly assimilated $\mathrm{C}$ into PLFA or NLFA biomarkers $\left(\mathrm{C}_{\mathrm{PLFA}}\right.$ or $\left.\mathrm{C}_{\mathrm{PLFA}}\right)$ of each sample, the $\% \mathrm{C}_{\mathrm{F}_{\text {P PLFA }}}$ or $\% \mathrm{C}_{\mathrm{F}_{-} \text {NLFA }}$ (calculated with Eq. 6 ) was divided by 100 , and the result was multiplied by the total PLFA or NLFA content of the labeled sample (L) and the total C content within each PLFA or NLFA molecule (Eq. 8),

$\operatorname{CPLFA}(\mu \mathrm{g}$ FC $)=\left(\frac{\% \text { CF_PLFA }}{100}\right) \times\left(\frac{\mathrm{M}(\mu \mathrm{g} \text { PLFA FC }-\mathrm{C})}{\mathrm{M}(\mu \mathrm{g} \text { PLFA FC })} \times \mu \mathrm{g}\right.$ PLFAL $)$

where ${ }^{13} \mathrm{C}_{\text {PLFA }}(\mu \mathrm{g} F \mathrm{~F})$ is the freshly assimilated $\mathrm{C}$ into PLFA or NLFA biomarkers, M(PLFA-C) is the molar mass of the $\mathrm{C}$ in the PLFA or NLFA molecule, and M(PLFA) is the molar mass of the PLFA or NLFA molecule. Once the freshly assimilated $\mathrm{C}$ contents were obtained in each of the biomarkers for each treatment, they were grouped according to the microbial group to which they belong (Table 1).

\section{Leaf areas}

The total leaf area $\left(\mathrm{cm}^{2}\right)$ for each plant was measured with a LI-3100C (Licor, Lincoln, NE, USA) after finishing the pulsechase labeling experiment. Deficiency in P nutrition has been recognized as an important factor reducing the size of the leaf area and consequently limiting light interception and the photosynthetic capacity of leaves (Rodríguez et al. 1998).

\section{Data analysis}

For both experiments, normality of the data was verified with the Shapiro-Wilk's test and homogeneity of variances using the Levene's test. One-way ANOVA analysis and the Duncan post hoc test was employed for mean separation $(p<0.05)$ between the different $\mathrm{P}$ sources offered at the fungal compartment for the different variables at each time point. Data analysis was performed using SPSS v.24 for Windows (IBM Corporation 2016).

\section{Results}

\section{Experiment 1}

P derived from the all three sources was incorporated into the different AM plants, starting from day 35 and lasting until the 
Table 1 List of analyzed fatty acid biomarkers and their associated microbial group

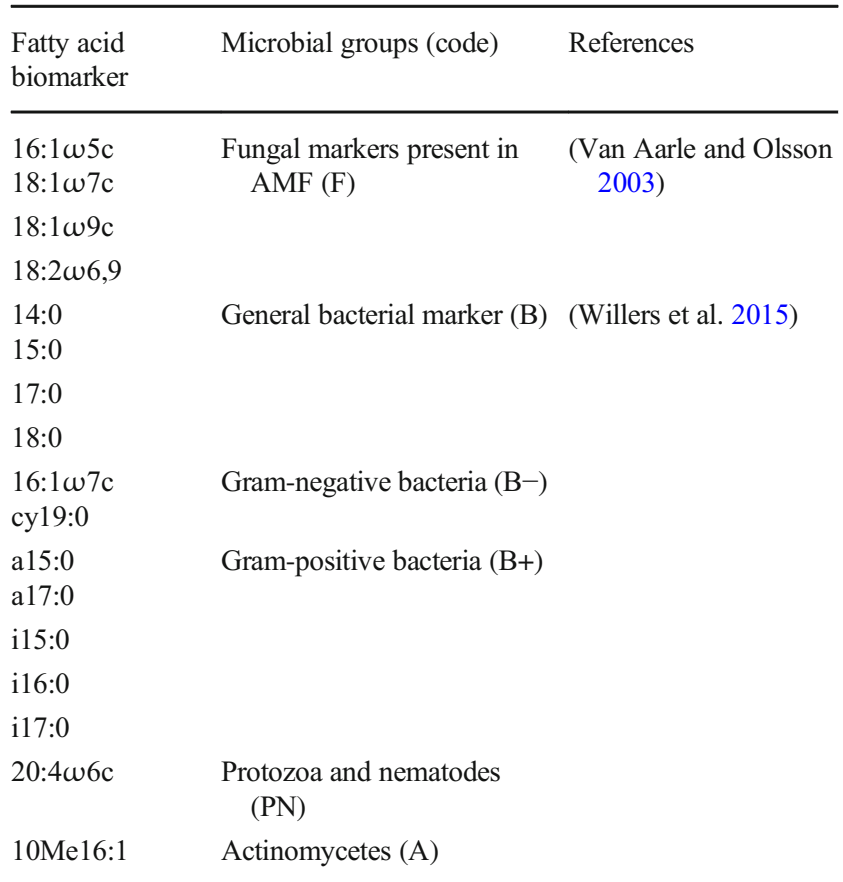

end of the experiment at day 112 (Fig. 2). Control mycorrhizal plants without access to a $\mathrm{P}$ source $(\mathrm{M}+)$ did not show any $\mathrm{P}$ incorporation. No significant differences were observed in $\mathrm{P}$ incorporation on day 35 , but there were significant differences on day 56 for AM plants accessing PA. At day 84, all AM plants with access to a $P$ source exhibited the largest $P$ incorporation without a significant difference between the treatments regarding $\mathrm{P}$ uptake, and the mineral $\mathrm{P}$ source yielded greater amount than the $0.09 \mathrm{mg} \mathrm{P}$ available by the pure dissolution of AP. At day 112, the inorganic P forms OP and AP facilitated significantly more $\mathrm{P}$ for plant growth than for $\mathrm{PA}$ (Fig. 2). Furthermore, shoot and root biomass (Fig. S1) exhibited that control plants $(\mathrm{M}+)$ show a tendency to increase root biomass, contrary to the shoots at days 84 and 112, compared with the other three treatments with access to a $\mathrm{P}$ source.

The ratio of cumulative $\mathrm{CO}_{2}-\mathrm{C}$ production $(\mathrm{mg})$ to $\mathrm{OC}$ content (mg) in the fungal chamber was significantly larger for those AM plants that had access to AP during the experiment, as compared with that of $\mathrm{OP}, \mathrm{PA}$, and the $\mathrm{M}+$ control (Fig. 3).

Those AM plants that incorporated P from PA showed higher PLFA and NLFA 16:1 $1 \omega 5 \mathrm{c}$ to $\mathrm{P}$ ratios than the OP and AP treatments at days 35 and 84 (Fig. $4 \mathrm{a}$ and b). At day 112 , only the PLFA $16: 1 \omega 5$ c to $\mathrm{P}$ ratio was significantly larger for AP and PA as compared with the OP. With incubation time, at days 84 and 112 , the NLFA $16: 1 \omega 5$ c to PLFA $16: 1 \omega 5 \mathrm{c}$ ratio increased for all AM plants mobilizing a $\mathrm{P}$ source in the fungal compartment in contrast to the $\mathrm{M}+$ control (Fig. 4c).

\section{Experiment 2}

Since AM plants with access to a P source exhibited the largest $\mathrm{P}$ incorporation and did not show any significant differences in the amount of $\mathrm{P}$ incorporated from each source at day 84 , a new set of plants was labeled on the same day for comparing the current costs of $\mathrm{P}$ acquisition from the different sources.

In case of respired ${ }^{13} \mathrm{CO}_{2}$ derived from freshly assimilated $\mathrm{C}(\mu \mathrm{g})$ measured in the fungal compartment (Fig. 5), the Mcontrol, without mycorrhiza and without $\mathrm{P}$, showed a nonconstant ${ }^{13} \mathrm{CO}_{2}$ respiration over the $25.5 \mathrm{~h}$ pulse-chase experiment. In contrast, the $\mathrm{OP}$ and $\mathrm{M}+$ treatments exhibited an increasing content of ${ }^{13} \mathrm{C}(\mu \mathrm{g})$ in the respired $\mathrm{CO}_{2} 8 \mathrm{~h}$ after the pulse labeling. The treatment containing AP exhibited significantly larger respired ${ }^{13} \mathrm{CO}_{2}(\mu \mathrm{g})$ as compared with $\mathrm{OP}$, $\mathrm{M}+$, and $\mathrm{M}-$ from the ninth hour onwards. In the case of PA treatment, there were significant differences to the other treatments after the first $3 \mathrm{~h}$ of the pulse-chase experiment. The AP and PA treatments kept a steadily increasing trend regarding the respired ${ }^{13} \mathrm{CO}_{2}(\mu \mathrm{g})$ which lasted until the end of the experiment (Fig. 5). Moreover, the sum of ${ }^{13} \mathrm{CO}_{2}$ respired over $25.5 \mathrm{~h}$ monitored was significantly largest in case of $\mathrm{PA}$, in comparison with treatments containing $\mathrm{OP}, \mathrm{AP}$, or M+ (Fig. 6).

Twenty-seven hours after labeling, the largest ${ }^{13} \mathrm{C}$ content $(\mathrm{mg})$ in the leaves was found in the AM plants accessing a $\mathrm{P}$ source in comparison with the $\mathrm{M}+$ control. AM plants mobilizing OP and PA showed the largest ${ }^{13} \mathrm{C}$ content $(\mathrm{mg})$ in

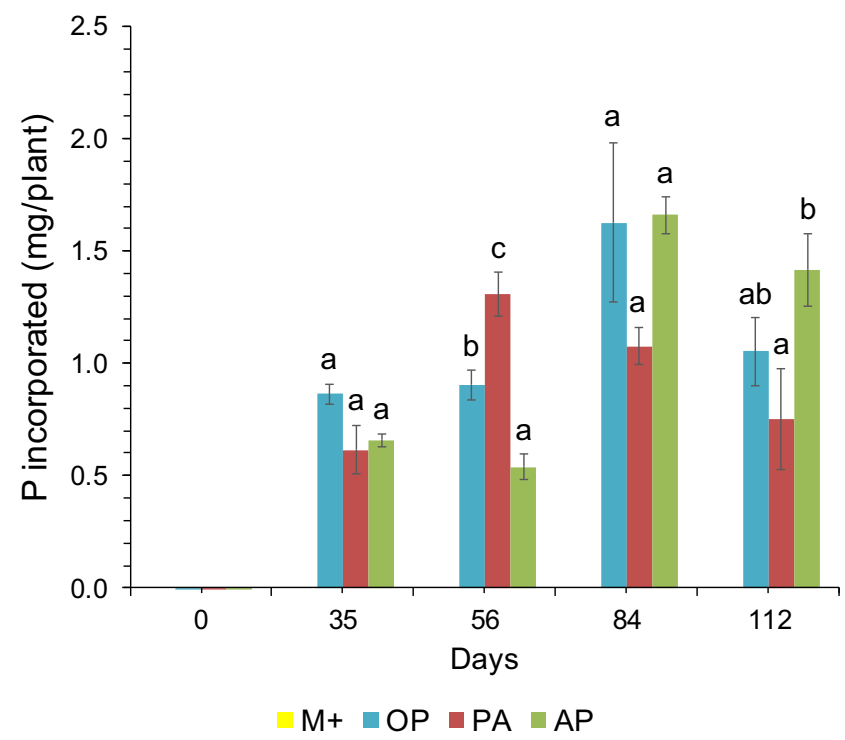

Fig. 2 Phosphorus incorporated into the arbuscular mycorrhizal plant along the time-course experiment (mean values \pm standard error, $n=3$ ). No $\mathrm{P}$ was incorporated in the $\mathrm{M}+$ treatment. Within each $\mathrm{P}$ source, treatments with significant differences are indicated by different small letters $(p<0.05)$ as analyzed by one-way ANOVA. Abbreviations are OP, orthophosphate; AP, apatite; PA, phytic acid; M+, mycorrhizal plant with no $P$ 


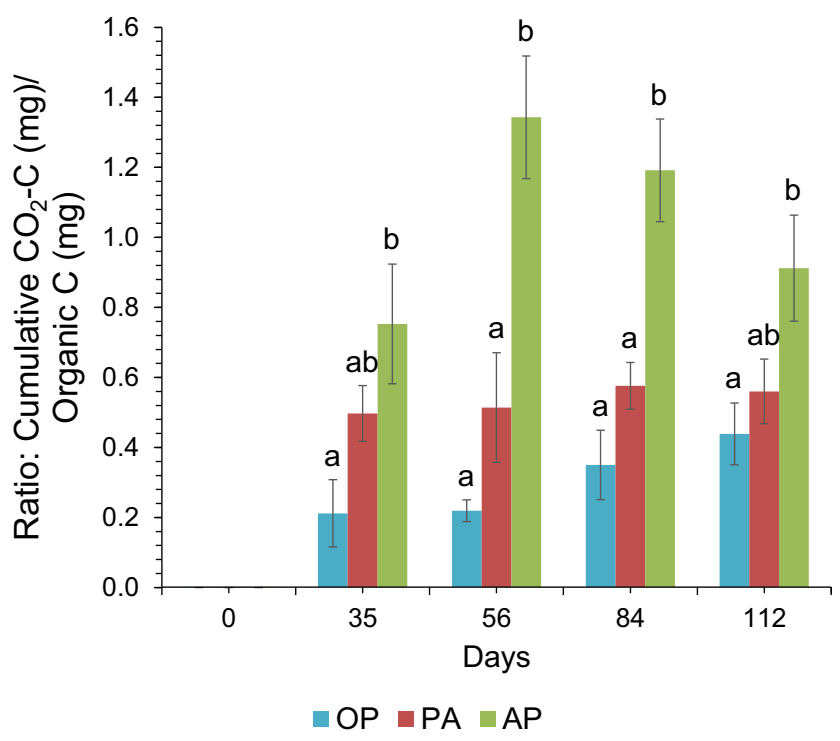

Fig. 3 Ratio of respired cumulative $\mathrm{CO}_{2}-\mathrm{C}(\mathrm{mg})$ and the accumulated organic $\mathrm{C}(\mathrm{mg})$ for the fungal compartment containing the different $\mathrm{P}$ sources (mean values \pm standard error, $n=3$ ). Within each $\mathrm{P}$ source, treatments with significant differences are indicated by different small letters $(p<0.05)$ as analyzed by one-way ANOVA. Abbreviations are OP, orthophosphate; AP, apatite; PA, phytic acid

leaves, followed by AM plants with access to AP in the fungal compartment. Furthermore, the ${ }^{13} \mathrm{C}$ content $(\mathrm{mg})$ in the leaves represented around $60 \%$ of the total freshly assimilated $\mathrm{C}$ in case of AM plants mobilizing OP, which is more than for all others. In addition, AM plants with access to OP exhibited larger leaf areas and photosynthesis rates than the PA, AP, or $\mathrm{M}+$ treatments. In the shoot tissues, the largest ${ }^{13} \mathrm{C}$ content (mg) was found in the AM plants that accessed PA in comparison with treatments containing $\mathrm{OP}, \mathrm{AP}$, or M+ (Fig. 6). In case of the root samples, AM plants mobilizing AP over their mycorrhizal partner exhibited a larger ${ }^{13} \mathrm{C}$ content $(\mathrm{mg})$ as compared with those mobilizing PA, OP, or $\mathrm{M}+$. The ${ }^{13} \mathrm{C}$ content (mg) in the plant and fungal compartment substrates derived from freshly assimilated $\mathrm{C}$ was larger in all the AM plants that accessed a $\mathrm{P}$ source in comparison to the $\mathrm{M}+$ control (Fig. 6).

Among the 17 studied PLFA biomarkers, only 11 were labeled with ${ }^{13} \mathrm{C}(14: 0$, a15:0, i15:0, 15:0, 16:1w7c, 16:1w5c, 17:0, 18:2w6, 9, 18:1w9c, 18:1w7c, 18:0). The PLFA AMF biomarker contained more than $96 \%$ of ${ }^{13} \mathrm{C}$ derived from freshly assimilated $\mathrm{C}$ within the PLFA biomarkers for all AM plants accessing a $\mathrm{P}$ source, in contrast to the $\mathrm{M}+$ test with only $84 \%$ assimilated ${ }^{13} \mathrm{C}$ into the $\mathrm{AMF}$ biomarkers (Fig. 7a). For the NLFA samples, only the AMF biomarker (16:1w5c) showed ${ }^{13} \mathrm{C}$ enrichment. The ${ }^{13} \mathrm{C}$ contents $(\mu \mathrm{g})$ in the AMF biomarkers differed between the treatments; those treatments with access to PA, AP, and OP showed larger ${ }^{13} \mathrm{C}$ contents $(\mu \mathrm{g})$ compared with the $\mathrm{M}+$ treatment (Fig. 7a). The relative amounts of recently assimilated $\mathrm{C}$ in the general biomarkers of bacteria (B) were not plotted in Fig. 7b, as they were up to an order of magnitude lower than the rest of the bacterial markers. The Gram-positive (B+) and Gramnegative (B-) PLFA biomarkers showed a minor percentage of ${ }^{13} \mathrm{C}(<0.3 \% \mathrm{~B}+;<3.4 \% \mathrm{~B}-)$ derived from freshly assimilated $\mathrm{C}$ for all treatments containing a $\mathrm{P}$ source when compared with the $\mathrm{M}+$ treatment $(7.4 \% \mathrm{~B}+; 8.8 \% \mathrm{~B}-)$ (Fig. $7 \mathrm{~b})$. The NLFA AMF biomarkers exhibited the largest content of ${ }^{13} \mathrm{C}(\mu \mathrm{g})$ derived from freshly assimilated $\mathrm{C}$ for the PA treatment followed by AP and OP in contrast to the $\mathrm{M}+$ control (Fig. 7c).

\section{Discussion}

We tested the ability of $R$. irregularis taking up $\mathrm{P}$ from three different sources of different availability. To that end, we performed two consecutive experiments; in experiment 1 , we investigated whether a $\mathrm{C}$ for $\mathrm{P}$ trading by the $\mathrm{AM}$ plants exists at mobilization of $\mathrm{P}$ derived from sources with different availability. In experiment 2, we explored the fate of freshly assimilated $\mathrm{C}$ derived to nourish the $\mathrm{AMF}$ mobilizing the different $\mathrm{P}$ sources. We decided on the 84th day of the sampling, because AM plants exhibited the larger $P$ incorporation and not exhibited any significant differences in the amount of $\mathrm{P}$ incorporated from each source.

\section{Experiment 1}

\section{Phosphorus uptake from different accessible sources by the arbuscular mycorrhiza symbiosis}

The $\mathrm{P}$ sources were exclusively mobilized by the AMF and incorporated in different amounts into the plant tissues (Fig. 2). Additionally, the results of higher shoot to root biomass (Fig. S1) in those treatments mobilizing a P source are consistent with those ones previously discussed by Veresoglou et al. (2012), since fungal symbionts are more efficient scavengers for soil nutrients than plant roots; thus, root dry weight allocation would be lower with mycorrhizal fungi, as they would substitute for root uptake. Hence, it is expected that alleviation of host nutrient limitation due to inoculation by AMF may decrease plant root-to-shoot ratio, compared with non-mycorrhizal plants due to improved plant nutrient status (Holste et al. 2016). The AM fungal extraradical mycelium can directly acquire phosphate ions in the form of OP beyond the P depletion zone (Hodge 2017). Thus, our results demonstrated the suitability of the double-membrane system which prevented the influence of the roots on the P uptake, and therefore proved the importance of $R$. irregularis taking up $\mathrm{P}$ derived from the different sources.

The PA needs to be hydrolyzed by phytases of plant or microbial origin for its mineralization and phosphate release (Baldwin et al. 2001). R. irregularis DAOM 197198 is able to 

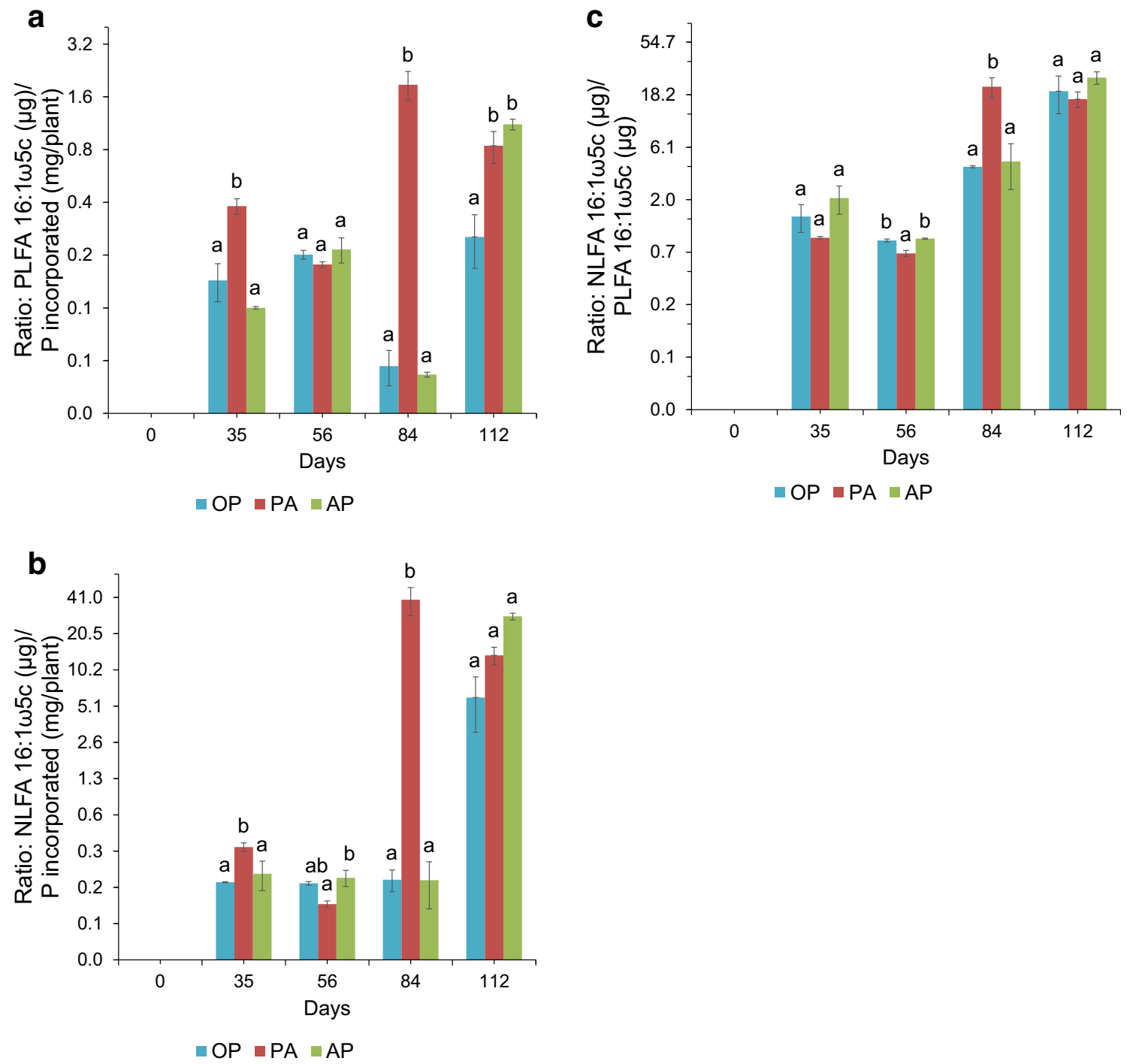

Fig. 4 Ratios of PLFA 16:1 $1 \omega 5 \mathrm{c}$ to P incorporated within the tomato plant (a), of NLFA16:1 $1 \omega 5 \mathrm{c}$ to P incorporated (logarithmic scale) within the

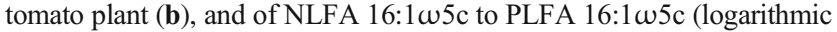
scale) from the different $\mathrm{P}$ sources along the time-course experiment

secrete a type of acid phosphatase, which contributes to the PA mineralization (Tisserant et al. 2012). Several studies have shown the ability of Rhizophagus species to hydrolyze organic $\mathrm{P}$ and transfer it through the mycelium and making a significant contribution to plant $\mathrm{P}$ uptake from sources such as lecithin, RNA, and PA (Koide and Kabir 2000; Sato et al. 2015). Utilization of organic $\mathrm{P}$ is thus assumed to contribute to $\mathrm{AM}$ plant $\mathrm{P}$ nutrition as inorganic P. Likewise, we did not observe significant differences between the amounts of $P$ mobilized from $\mathrm{PA}$ and OP during most of the time of the experiment.

We observed that the AM plant mobilizing the AP clearly incorporated more $\mathrm{P}$ than was soluble in water, a fact that points out to an active biological weathering. It is widely accepted that AM plants can access the P contained in the AP by joint action of roots and hyphae (Murdoch et al.

(mean values \pm standard error, $n=3$ ). Within each $\mathrm{P}$ source and day, treatments with significant differences are indicated by different small letters $(p<0.05)$ as analyzed by one-way ANOVA. Abbreviations are $\mathrm{OP}$, orthophosphate; AP, apatite; and PA, phytic acid

1967). Souchie et al. (2010) observed a greater clover growth rates in those treatments mycorrhized with AMF and fed with $\mathrm{AP}$, as the solely $\mathrm{P}$ source in comparison with the nonmycorrhized treatments. The AM hyphae appear to enter AP mineral structures, while plant roots barely can take up P from primary minerals as they are too unreactive (Koele et al. 2014). Burghelea et al. (2015) observed in a similar approach as ours, that over 124 days, AM mycorrhized plant growth was enhanced in presence of rhyolite rocks, due to an efficient $P$ mining. Different authors have demonstrated the ability of AMF to mobilize P from AP, e.g., Rhizophagus fasciculatus and Rhizophagus tenuis (Powell and Daniel 1978), Rhizophagus manihotis (Ness and Vlek 2000), Rhizophagus clarum (Alloush and Clark 2001), and Gigaspora margarita (Ramirez et al. 2009), and Koele et al. (2014) found mineral 
Fig. 5 Cumulative $\mathrm{CO}_{2}$ respiration from the fungal compartment $(\mu \mathrm{g})$ derived from the freshly assimilated $\mathrm{C}$ after the ${ }^{13} \mathrm{C}$ pulse labeling. Mean values and standard errors of the respired $\mathrm{CO}_{2}(\mu \mathrm{g})$ of three independent mesocosms at different time points for each treatment. Within each P source, treatments with significant differences are indicated by different small letters $(p<0.05)$ as analyzed by oneway ANOVA. Abbreviations are OP, orthophosphate; AP, apatite; PA, phytic acid; M+, mycorrhizal plant with no $\mathrm{P} ; \mathrm{M}-$, nonmycorrhizal plant

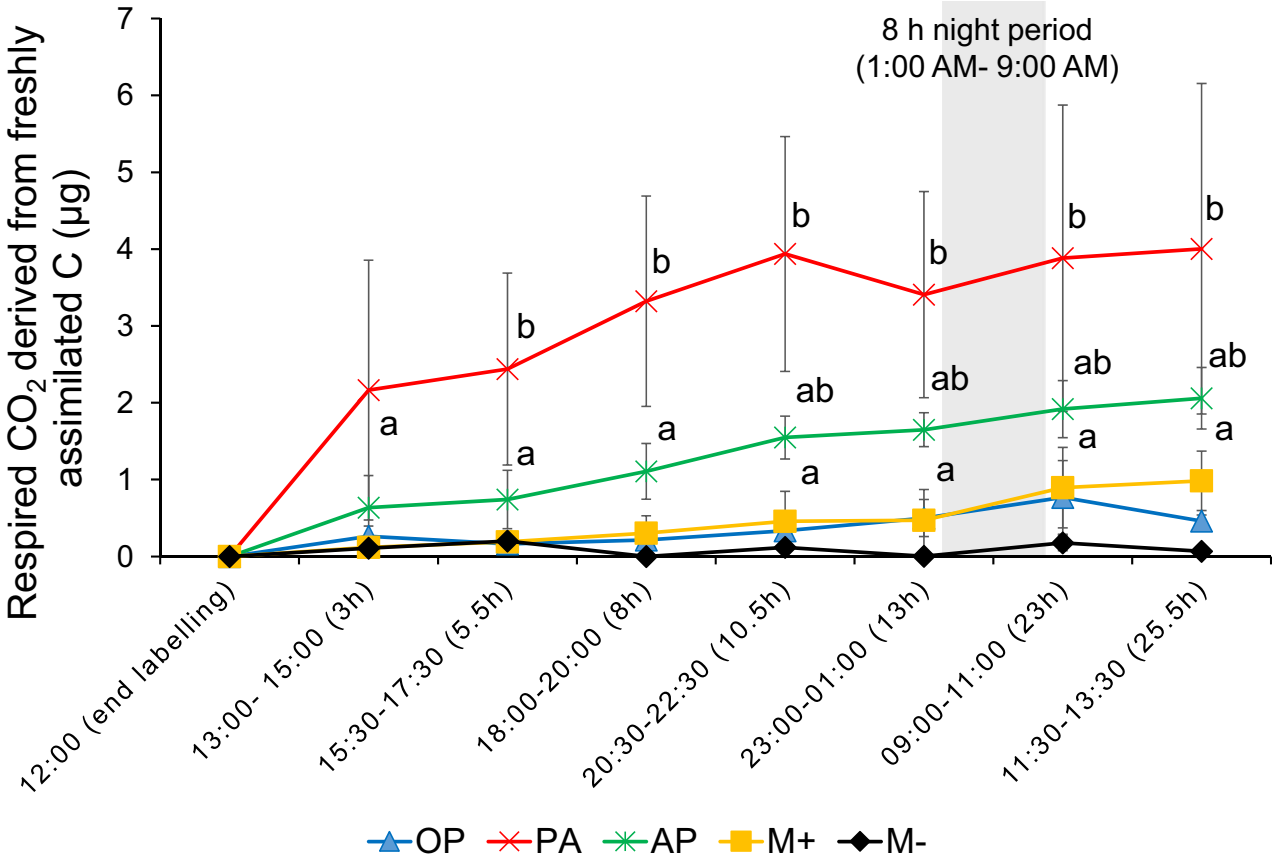

weathering "tunnels" under both arbuscular and ectomycorrhizal associations coupled to P uptake from AP. They pointed out to the rhizosphere acidification as one likely mechanism for the AP weathering by soil mycorrhizal fungi, saprotrophic fungi, and bacteria. Two recent papers have also investigated the abilities of $R$. irregularis in phosphate mobilization from AP (Taktek et al. 2017; Pel et al. 2018). Both publications showed the AMF utilizing poorly soluble AP to

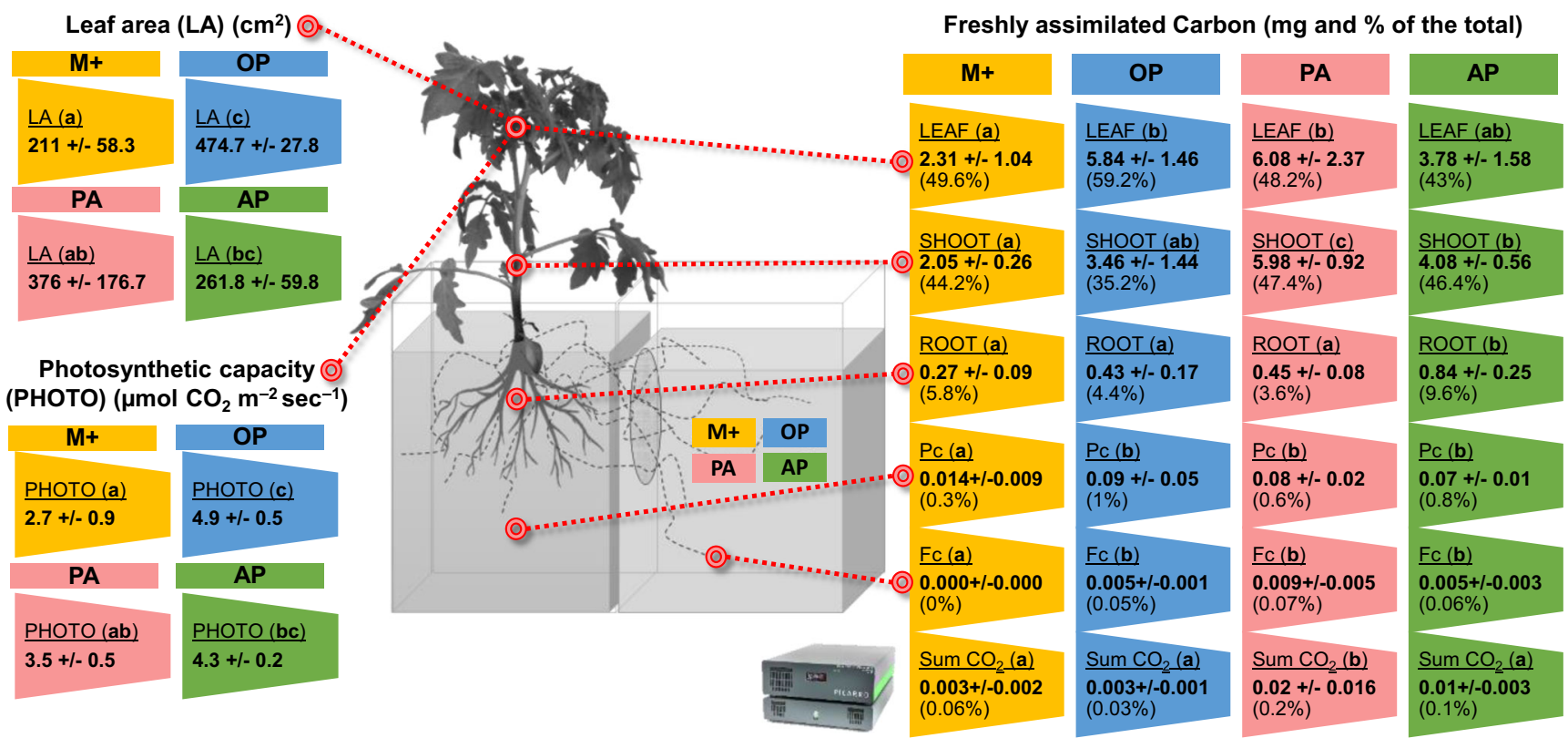

Fig. 6 Scheme containing the results of parameters measured before (photosynthetic capacity), during (freshly assimilated C), and after (leaf area) the ${ }^{13} \mathrm{C}$ pulse labeling experiment of the different mesocosms. The photosynthetic capacity of the plants that accessed the different $P$ sources immediately before the ${ }^{13} \mathrm{C}$ pulse labeling is shown on the lower left side, the leaf area for the different treatments is shown on the upper left side, and the freshly assimilated $\mathrm{C}$ at the different plant organs, fungal compartment $(\mathrm{Fc})$, and the cumulative $\mathrm{CO}_{2}$ respiration from the fungal compartment for the different treatments $24 \mathrm{~h}$ after the ${ }^{13} \mathrm{C}$ pulse-chase labeling is shown on the right side. In bold letters inside each colored cell, the mean value and the standard error is shown $(n=3)$ for each parameter. Between brackets, the mean percentage of freshly assimilated $\mathrm{C}$ into the plant organs, the fungal and plant compartments $(\mathrm{Pc})$, and the cumulative $\mathrm{CO}_{2}$ respiration is shown. Within each $\mathrm{P}$ source, treatments with significant differences are indicated by different small letters $(p<0.05)$ as analyzed by one-way ANOVA. Abbreviations are OP, orthophosphate; AP, apatite; PA, phytic acid; M+, mycorrhizal plant without P 
a

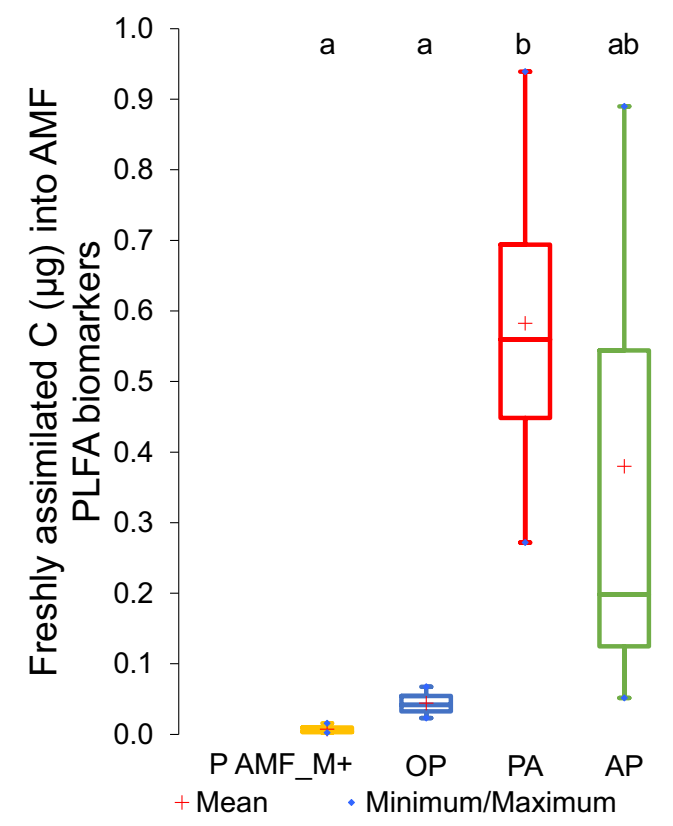

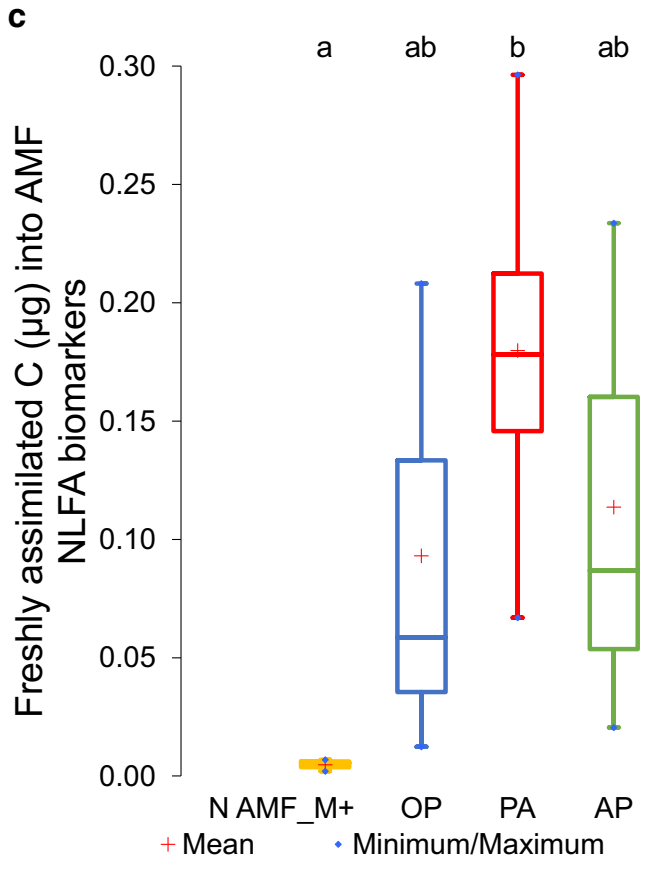

b

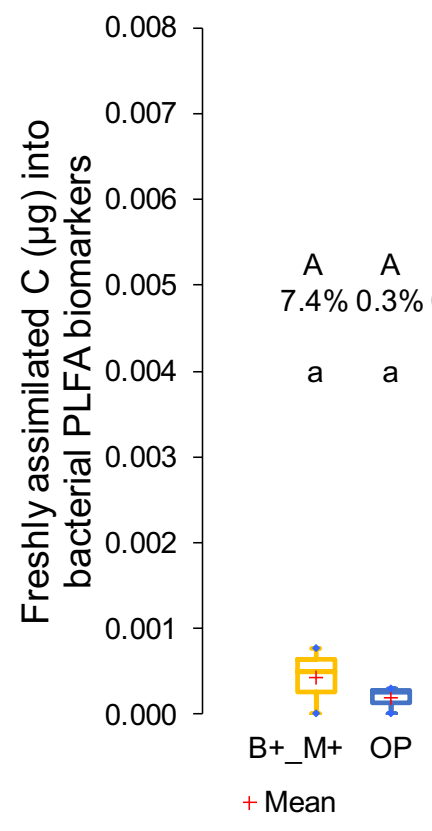

Fig. 7 Set of graphics displaying recently assimilated $\mathrm{C}$ results within different fractions of the microbial populations. (a) Box-plot showing the freshly assimilated C $(\mu \mathrm{g})$ into AMF PLFA biomarkers within the fungal compartment for the different $\mathrm{P}$ sources (mean values \pm standard error, $n=3)$. (b) Box-plot showing the freshly assimilated C $(\mu \mathrm{g})$ into bacterial PLFA biomarkers within the fungal compartment for the different phosphorus sources (mean values \pm standard error, $n=3$ ). On the right side, the $\mathrm{B}+$ stands for Gram-positive PLFA bacterial biomarker, and on the right side, B- for Gram-negative bacteria. (c) Box-plot showing the freshly assimilated $\mathrm{C}(\mu \mathrm{g})$ into AMF NLFA biomarkers in the fungal

\section{B}

$99.6 \%$

A $A B \quad B \quad B$

$8.8 \% 3.4 \% 0.7 \% 0.3 \%$

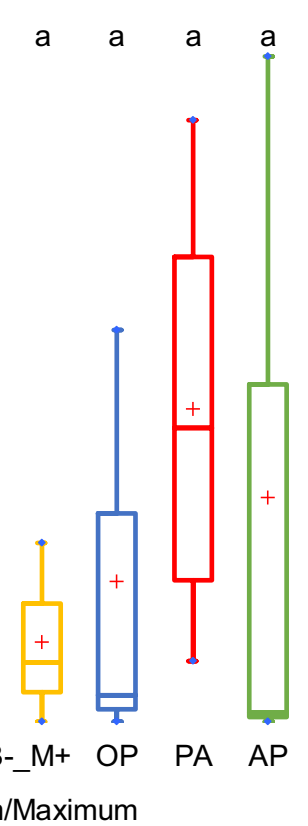


deliver phosphate to host plants. Compared with the study of Taktek et al. (2017), we used a complete plant and not a transformed root culture. We also found another significant difference with the investigation of Pel et al. (2018). Contrastingly to our experimental design, they did not spatially separate the AP from the roots. Thus, our mesocosms offered an advantageous design, where exclusively the hyphae of $R$. irregularis were able to mobilize the phosphate from OP, $\mathrm{PA}$, and the AP.

\section{Metabolic activity and development of $R$. irregularis under variable $P$ sources}

We used the respired $\mathrm{CO}_{2}-\mathrm{C}$ to $\mathrm{OC}$ ratio, as a proxy for the metabolic activity in the fungal compartment. The mesocosm design guaranteed that all $\mathrm{C}$ measured in the fungal compartment was exclusively carried by the AMF. The sources of respired $\mathrm{CO}_{2}$ in the fungal compartment include $R$. irregularis autotrophic respiration, plus the heterotrophic one derived from the associated microbiota and dead hyphae/ bacteria. The $\mathrm{CO}_{2}-\mathrm{C}$ to $\mathrm{OC}$ ratio was significantly higher for treatments containing PA and AP than OP until day 84 (Fig. 3 ), indicating a higher metabolic activity of AMF, in order to mobilize P from the least available sources. Thus, in our oneone system, the AMF seems to adjust its energy requirements precisely to the accessibility of the P sources. These results correspond to those already obtained in our previous study, where the less accessible $\mathrm{P}$ sources associated to iron oxides exhibited the highest metabolic activities (Andrino et al. 2019). Hence, it can be inferred that treatments containing less accessible $\mathrm{P}$ sources exhibited higher $\mathrm{C}$ investments in autotrophic and heterotrophic metabolic processes during $\mathrm{P}$ incorporation in the AM plant.

In addition to the metabolic activity, we used the ratios PLFA and NLFA $16: 1 \omega 5 \mathrm{c}$ to the total plant P uptake as indicators of energy investment into infrastructure and energy storage per $\mathrm{P}$ incorporated, respectively (Fig. $4 \mathrm{a}$ and $\mathrm{b}$ ). The PLFA 16:1 $\omega 5 \mathrm{c}$ to P and NLFA $16: 1 \omega 5 \mathrm{c}$ to $\mathrm{P}$ ratios showed higher values in those treatments mobilizing $P$ from PA and AP, compared with OP. One likely justification to increase the fungal infrastructure in the presence of $\mathrm{P}$ forms like PA and $\mathrm{AP}$ is the need to develop more extraradical hyphae to mobilize and transport P more efficiently to the host plant, as AMF tend to develop more extensively under low-nutrient conditions (Bryla and Eissenstat 2005). At low P availability, Raven (2018) hypothesized a greater C investment on AMF mycelium would be needed to support an increased construction and maintenance costs of the mycelium, as is likely the case in the PA and AP treatments, which need to be mineralized or weathered, respectively, before P uptake. Jansa et al. (2011) hypothesized on the existence of different mechanisms for $\mathrm{P}$ mobilization by AMF: scavenging of OP, solubilizing AP, and hydrolyzing PA. They assumed different turnover rates for AMF being associated to the different mobilization strategies. According to Jansa et al. (2011), long-lived hyphae represent an advantage in mobilizing hardly accessible $\mathrm{P}$ sources like AP or PA, once approached. Contrasting to this, they hypothesized short-lived hyphae in case of OP exploitation in soil, as here a quick exploration of larger soil volumes is key, and the process of scavenging OP from soil solution itself does not require comparable amounts of energy. Hence, our results may support the hypothesis of Jansa et al. (2011), meaning that even when the P source is reached by the AMF, it still is growing to assist the mobilization of less accessible sources, on which mineralization and/or weathering processes will take place. Finally, the NLFA $16: 1 \omega 5 \mathrm{c}$ to PLFA $16: 1 \omega 5 \mathrm{c}$ ratio (Fig. $4 \mathrm{c}$ ), an indicator of the preferential $\mathrm{C}$ allocation into lipid storage (Bååth 2003), suggests that AM plants mobilizing OP and AP required less energy storage, compared with those plants mobilizing PA at day 84 . The AM plants mobilizing PA exhibited a larger investment into AMF mycelium and metabolism in contrast to the ones mobilizing AP that showed a smaller investment into the AMF infrastructure but significantly higher metabolism. Our experiment revealed different $\mathrm{P}$ acquisition strategies that resulted in different $\mathrm{C}$ costs for the AM plant. This is in accordance with the hypothesis proposed by Turner (2008), in which the acquisition of the different $P$ compounds are classified by the energy investment that must be made to access the phosphate ions. Thus, under our experimental conditions, where AM plants took up P exclusively via the mycorrhizal pathway, we can deduce different trading costs of $\mathrm{C}$ for $\mathrm{P}$, depending on the $\mathrm{P}$ source.

\section{Experiment 2}

To evaluate the current C-P trading costs made by the AM plants mobilizing the different $\mathrm{P}$ sources, another set of 84day-old plants were labeled with ${ }^{13} \mathrm{CO}_{2}$, since no significant differences were observed during experiment 1 regarding the amount of $\mathrm{P}$ incorporated at day 84 . The selected time point offered us a unique opportunity to compare whether the different acquisition strategies described in experiment 1 entailed different energy investments to mobilize the $\mathrm{P}$ by tracing the pathways of the recent plant assimilates along the trophic chain of AMF and adjacent microbiota.

\section{Photosynthetic rates and leaf areas}

We measured the photosynthetic activity of each AM plant 1 day before the ${ }^{13} \mathrm{CO}_{2}$ pulse labeling. All AM plants mobilizing a $\mathrm{P}$ source showed significantly higher photosynthetic rates than the $\mathrm{M}+$ control. Additionally, the AM plants mobilizing OP exhibited the largest photosynthetic rates. As for the photosynthesis rates, also the foliar areas were greater in the AM plants mobilizing a $\mathrm{P}$ source, and plants mobilizing OP 
showed the greatest foliar areas (Fig. 6). At least three other studies have reported similar results to ours (Parádi et al. 2003; Wu and Xia 2006; Birhane et al. 2012), where AM plants with bigger leaf areas also showed a higher photosynthetic $\mathrm{CO}_{2}$ fixation. They attributed to a larger total $\mathrm{P}$ content in plant tissues as the main cause for the enhanced photosynthetic function, coupled to an enhanced $\mathrm{C}$ fixation derived into the AMF, in comparison with non-AM plants. Thus, our results point towards AM plants mobilizing $\mathrm{P}$ from the different sources and increased their photosynthetic activity and leaf area sizes, to keep a larger photosynthate transfer into the AMF.

\section{Freshly assimilated $\mathrm{C}$ measured in the respired $\mathrm{CO}_{2}$ and the plant tissues}

We used the respired $\mathrm{CO}_{2}$ at the fungal compartment as a proxy for the current metabolic activity in the fungal compartment, as AMF receive the recently fixed photosynthates from their host plants, using it for their growth, respiration, and biological maintenance (Jansa et al. 2011). In nutrientdeficient soils, the AMF extraradical mycelium can account as a major source of $\mathrm{CO}_{2}$ efflux, thus becoming an important pathway of $\mathrm{C}$ flux from host plants to the atmosphere (Tomè et al. 2016). We focused our efforts on accurately registering the first respiration hours in the fungal compartment, as Grimoldi et al. (2006), Moyano et al. (2007), and Bahn et al. (2009) demonstrated that AM mycelia may provide a rapid and important pathway of $\mathrm{C}$ flux from plants to the soil and atmosphere, providing evidence of direct respiratory losses by AMF. Johnson et al. (2002) also highlighted the value of thorough surveys to track short-term $\mathrm{C}$ transfer dynamics of AM plants to soil, as many studies perform pulse labeling trials with relatively long fixation periods or have collected samples many hours after the end of labeling and consequently may have overlooked the maximum $\mathrm{C}$ yields from roots to AMF. Unlike experiment 1 , in experiment 2 , the short observation time implies that only autotrophic respiration was determined at the fungal compartment. However, as we observed in experiment 1 (Fig. 3), the results of experiment 2 also exhibited higher metabolic rates in those AM plants mobilizing PA and AP than taking up OP (Fig. 5). In line with Bahn et al. (2009), we detected that the new photoassimilates were transported and respired belowground within the first $3 \mathrm{~h}$ after the pulse labeling started, for the AM plants mobilizing PA. And similar to our results, Johnson et al. (2002) showed that the release of ${ }^{13} \mathrm{CO}_{2}$ from AMF peaked 9-14 $\mathrm{h}$ after labeling and during the first $21 \mathrm{~h}$. Most of the $\mathrm{C}$ lost by the plants was respired by the AMF and mostly declined after the first $24 \mathrm{~h}$. At the end of the respiration monitoring in the fungal compartment, $\mathrm{AM}$ plants mobilizing P from the PA showed the significantly largest cumulative ${ }^{13} \mathrm{CO}_{2}$ (Fig. 6, pointing to a greater $\mathrm{C}$ investment to mobilize as for the other treatments.
The ${ }^{13} \mathrm{C}$ contents in the leaves, shoots, roots, and substrates from plant and fungal compartments were significantly larger for treatments mobilizing OP, PA, and AP than those for the $M+$ treatment. This fits to the report of Johnson (2010) that AM plants might partition more $\mathrm{C}$ belowground under $\mathrm{P}$ limiting conditions to develop the capacity for soil $\mathrm{P}$ extraction. The model of Johnson (2010) predicts a mutualistic outcome of AM symbioses, depending on the stoichiometry of available $\mathrm{N}$ and $\mathrm{P}$. There will be mutualistic benefits at no $\mathrm{N}$ limitation and low $\mathrm{P}$ availability because a non-limited $\mathrm{N}$ supply tends to increase the photosynthetic capacity of the host plant. In our experimental design, the $\mathrm{N}$ was not limited since it was applied in the nutrient solution weekly. Our results corroborate Johnson's postulates, since all AM plants that mobilized and incorporated a $\mathrm{P}$ source exhibited larger photosynthetic capacity, foliar areas, and ${ }^{13} \mathrm{C}$ contents in all the plant tissue compartments compared with that of the $\mathrm{M}+$ treatment (Fig. 6), to supply more $\mathrm{C}$ to the AMF for mining the $\mathrm{P}$ sources of lower availability.

\section{Freshly assimilated C incorporated into different microbial communities}

We traced the fate of the freshly assimilated $\mathrm{C}$ into the microbial communities of the fungal compartments by fatty acid biomarkers (Fig. 7. Our results revealed that treatments with P application frequently showed the largest ${ }^{13} \mathrm{C}$ content in the AMF hyphae along with the significantly lowest ${ }^{13} \mathrm{C}$ values in the bacterial biomarkers. Only a fraction was delivered to AMF accompanying microbiota, since we inoculated the tomato plants with the strain of $R$. irregularis DOAM 197198 not grown in a monoxenic culture, thus carrying the microorganisms naturally associated with its hyphosphere. Zhang et al. (2016) pointed out that the AMF interactions with specific bacteria depend upon background $\mathrm{P}$ availability. The AMF may act as a rapid hub for recent photosynthates providing important niches to hyphae-associated soil bacterial communities which are generally composed of specific assemblages of species that differ from those in the bulk soil (Kaiser et al. 2015). The hyphae of AMF may provide an increased area for interactions with other soil microorganisms, especially bacteria, which may in turn synergistically interact with AMF and thereby promote plant growth (Taktek et al. 2015). Among the most effective bacterial phosphate solubilizers are species of the B+ genera Streptomyces, Kocuria, Arthrobacter, Nocardiodes, Microbacterium, Bacillus, and the B- genera Pseudomonas, Enterobacter, Burkholderia, Serratia, Citrobacter, Xanthomonas, Rhizobium, Azospirillum, and Klebsiella (Battini et al. 2016; Osorio et al. 2017). The mechanisms to access the more stable $\mathrm{P}$ forms include phosphatase synthesis (e.g., acid phosphatase, phytase), soil pH lowering, and/or ligand exchange reactions mediated by low molecular weight organic acids (Osorio et al. 2017). Although not significantly different from the M+control, treatments with PA and AP 
in their fungal compartments displayed the largest absolute ${ }^{13} \mathrm{C}$ contents in $\mathrm{B}-$ bacterial biomarkers $27 \mathrm{~h}$ after ${ }^{13} \mathrm{CO}_{2}$ labeling (Fig. 7b). The results show AMF altering the diversity and structure of bacterial communities in the fungal compartment and fueling $\mathrm{P}$ weathering (AP) or hydrolyzation (PA). In this regard, Kim et al. (1998) and Taktek et al. $(2015,2017)$ suggested a synergistic interaction between the hyphobacteria able to solubilize insoluble phosphate and an AMF to mobilize P from AP. A similar reasoning was made by Selvakumar et al. (2016), Lecomte et al. (2011), and Battini et al. (2016), who showed a synergistic interaction between the AMF and some bacteria with abilities to mineralize the PA. We estimated the cost of establishing an AM by means of the NLFA 16:1 $1 \omega 5 \mathrm{c}$ biomarker (Bååth 2003), since the AM pathway seems to respond quickly to changing soil nutrient by adapting the amount of plant $\mathrm{C}$ channeled through the fungus (Kaiser et al. 2015). The NLFA $16: 1 \omega 5 \mathrm{c}$ is stored in intraradical vesicles, spores, extraradical mycelium, and metabolized in the mycelium through the glyoxalate cycle, providing the major fungal energy source as respiratory substrate (Olsson and Johnson 2005). The freshly assimilated $\mathrm{C}$ incorporated into AMF NLFA biomarkers clearly indicated that PA was the P source with the most expensive acquisition cost, followed by $\mathrm{AP}$ and $\mathrm{OP}$ in contrast to the M+ control (Fig. 7c). In summary, AM plants with access to PA and AP diversified the fate of recently assimilated $\mathrm{C}$, incorporating it into the PLFA and NLFA 16:1 $1 \omega 5 \mathrm{c}$. The more stable and therefore less available $P$ sources $P A$ and AP received greater amounts of photosynthates that were invested in further growth (PLFA 16:1 $\omega 5 \mathrm{c}$ ) and energy accumulation (NLFA 16:1 $\omega 5 \mathrm{c}$ ), along with a potential contribution of $\mathrm{B}-$ bacteria in the mobilization of phosphate from both $\mathrm{P}$ sources.

\section{Conclusions}

In this study, we showed that $\mathrm{AM}$ plants took up $\mathrm{P}$ derived from orthophosphate (OP), apatite (AP), and phytic acid (PA) exclusively via the mycorrhizal pathway with different C-P trading costs. We identified different $\mathrm{P}$ acquisition strategies to mobilize the less available P sources PA and AP. In the fungal compartment, both sources exhibited the largest investments into fungal infrastructure (PLFA) and the largest metabolic rates $\left(\mathrm{CO}_{2}-\mathrm{C} / \mathrm{OC}\right)$. Our results suggest that the less available $\mathrm{P}$ sources require more long-living mycelium infrastructure with higher metabolic rates, in contrast to the OP with a faster hyphal turnover and lower requirements of freshly assimilated C. We also observed that B- bacteria may contribute to $\mathrm{P}$ acquisition from $\mathrm{PA}$ and $\mathrm{AP}$, suggesting a synergistic cooperation occur between both organisms. The $\mathrm{C}$ investments into $\mathrm{P}$ mobilization from $\mathrm{P}$ sources with differing accessibilities suggests the existence of a nexus between AMF $P$ mining strategies and the amounts of $\mathrm{C}$ accumulated in terrestrial soils.
Acknowledgments The authors would like to thank Dr. Axel Don and Dr. Reinhard Well for opening the doors of the Thünen Institute for developing part of the experiment. The authors are also thankful for the great help and guidance received by Dr. Norman Gentsch, Silke Bokeloh, Elke Eichmann-Prusch, Anne Katrin Herwig, Ulrike Pieper, Heike Steffen, and Michael Klatt.

Availability of data and material Raw and derived data supporting the findings of this study are available from the corresponding author Alberto Andrino on request.

Code availability Not applicable.

Author contribution Jens Boy, Georg Guggenberger, and Alberto Andrino designed the experiment. Alberto Andrino prepared the plant and fungal material. Stefan Burkart and Alberto Andrino carried out the Picarro measurements at the Institute of Climate Smart Agriculture facilities. Alberto Andrino conducted the experiment and analyzed the data. Jens Boy, Leopold Sauheitl, and Georg Guggenberger supervised the research. Alberto Andrino wrote the paper with contributions from Jens Boy, Georg Guggenberger, Leopold Sauheitl, and Stefan Burkart. All authors read and approved the final manuscript.

Funding information Open Access funding provided by Projekt DEAL. Funding was provided within the Research Training Group 1798 "PlantSoil-Interfaces" (PSI) of the Deutsche Forschungsgemeinschaft (DFG).

\section{Compliance with ethical standards}

Conflict of interest The authors declare that they have no conflict of interest.

Ethical approval Not applicable.

Consent to participate Not applicable.

Consent for publication Not applicable

Open Access This article is licensed under a Creative Commons Attribution 4.0 International License, which permits use, sharing, adaptation, distribution and reproduction in any medium or format, as long as you give appropriate credit to the original author(s) and the source, provide a link to the Creative Commons licence, and indicate if changes were made. The images or other third party material in this article are included in the article's Creative Commons licence, unless indicated otherwise in a credit line to the material. If material is not included in the article's Creative Commons licence and your intended use is not permitted by statutory regulation or exceeds the permitted use, you will need to obtain permission directly from the copyright holder. To view a copy of this licence, visit http://creativecommons.org/licenses/by/4.0/.

\section{References}

Alloush GA, Clark RB (2001) Maize response to phosphate rock and arbuscular mycorrhizal fungi in acidic soil. Commun Soil Sci Plant Anal 32:231-254. https://doi.org/10.1081/CSS-100103004

Andrino A, Boy J, Mikutta R, Sauheitl L, Guggenberger G (2019) Carbon investment required for the mobilization of inorganic and organic phosphorus bound to goethite by an arbuscular mycorrhiza (Solanum lycopersicum x Rhizophagus irregularis). Front Environ Sci 7. https://doi.org/10.3389/fenvs.2019.00026 
Arcand MM, Schneider KD (2006) Plant- and microbial-based mechanisms to improve the agronomic effectiveness of phosphate rock: a review. An Acad Bras Cienc 78:791-807. https://doi.org/10.1590/ S0001-37652006000400013

Arif MS, Shahzad SM, Yasmeen T, Riaz M, Ashraf M, Ashraf MA, Mubarik MS, Kausar R (2017) Improving plant phosphorus (P) acquisition by phosphate-solubilizing bacteria. In: Naeem M, Ansari AA, Sarvajeet Singh G (eds) Essential plant nutrients. Springer International Publishing, Cham, pp 513-556

Augé RM, Toler HD, Saxton AM (2016) Mycorrhizal stimulation of Leaf gas exchange in relation to root colonization, shoot size, leaf phosphorus and nitrogen: a quantitative analysis of the literature using meta-regression. Front Plant Sci 7:1084. https://doi.org/10.3389/ fpls.2016.01084

Bååth E (2003) The use of neutral lipid fatty acids to indicate the physiological conditions of soil fungi. Microb Ecol 45:373-383. https:// doi.org/10.1007/s00248-003-2002-y

Bahn M, Schmitt M, Siegwolf R, Richter A, Brüggemann N, Bahn M (2009) Does photosynthesis affect grassland soil-respired $\mathrm{CO}_{2}$ and its carbon isotope composition on a diurnal timescale? New Phytol 182:451-460. https://doi.org/10.2307/30225853

Baldwin JC, Karthikeyan AS, Raghothama KG (2001) LEPS2, a phosphorus starvation-induced novel acid phosphatase from tomato. Plant Physiol 125:728-737. https://doi.org/10.1104/pp.125.2.728

Battini F, Cristani C, Giovannetti M, Agnolucci M (2016) Multifunctionality and diversity of culturable bacterial communities strictly associated with spores of the plant beneficial symbiont Rhizophagus intraradices. Microbiol Res 183:68-79. https://doi. org/10.1016/j.micres.2015.11.012

Birhane E, Sterck FJ, Fetene M, Bongers F, Kuyper TW (2012) Arbuscular mycorrhizal fungi enhance photosynthesis, water use efficiency, and growth of frankincense seedlings under pulsed water availability conditions. Oecologia 169:895-904. https://doi.org/10. 1007/s00442-012-2258-3

Bischoff N, Mikutta R, Shibistova O, Puzanov A, Reichert E, Silanteva M, Grebennikova A, Schaarschmidt F, Heinicke S, Guggenberger G (2016) Land-use change under different climatic conditions: consequences for organic matter and microbial communities in Siberian steppe soils. Agric Ecosyst Environ 235:253-264. https://doi.org/ 10.1016/j.agee.2016.10.022

Brundrett M, Bougher N, Dell B, Grove T, Malajczuk N (1996) Working with mycorrhizas in forestry and agriculture. Australian Centre for International Agricultural Research, Canberra

Bryla DR, Eissenstat DM (2005) Respiratory costs of mycorrhizal associations. In: Lambers H, Ribas-Carbo M (eds) Plant Respiration. Springer, Dordrecht, pp 207-219

Burghelea C, Zaharescu DG, Dontsova K, Maier R, Huxman T, Chorover J (2015) Mineral nutrient mobilization by plants from rock: influence of rock type and arbuscular mycorrhiza. Biogeochemistry 124: 187-203. https://doi.org/10.1007/s10533-015-0092-5

Cozzolino V, Di Meo V, Monda H, Spaccini R, Piccolo A (2016) The molecular characteristics of compost affect plant growth, arbuscular mycorrhizal fungi, and soil microbial community composition. Biol Fertil Soils 52:15-29. https://doi.org/10.1007/s00374-015-1046-8

Daubois L, Beaudet D, Hijri M, De La Providencia I (2016) Independent mitochondrial and nuclear exchanges arising in Rhizophagus irregularis crossed-isolates support the presence of a mitochondrial segregation mechanism. BMC Microbiol 16:1-12. https://doi.org/ 10.1186/s12866-016-0627-5

Douds DD, Johnson NC (2007) Contributions of arbuscular mycorrhizas to soil biological fertility. In: Abbott LK, Murphy DV (eds) Soil biological fertility: a key to sustainable land use in agriculture. Springer, Dordrecht, pp 129-162

Fan Y, Lin F, Yang L, Zhong X, Wang M, Zhou J, Chen Y, Yang Y (2018) Decreased soil organic P fraction associated with ectomycorrhizal fungal activity to meet increased $\mathrm{P}$ demand under
$\mathrm{N}$ application in a subtropical forest ecosystem. Biol Fertil Soils 54: 149-161. https://doi.org/10.1007/s00374-017-1251-8

Fitter AH, Graves JD, Watkins NK, Robinson D, Scrimgeour C (1998) Carbon transfer between plants and its control in networks of arbuscular mycorrhizas. Funct Ecol 12:406-412. https://doi.org/10. 1046/j.1365-2435.1998.00206.x

Frostegård Å, Tunlid A, Bååth E (1991) Microbial biomass measured as total lipid phosphate in soils of different organic content. J Microbiol Methods 14:151-163. https://doi.org/10.1016/0167-7012(91) 90018-L

Gavito ME, Jakobsen I, Mikkelsen TN, Mora F (2019) Direct evidence for modulation of photosynthesis by an arbuscular mycorrhizainduced carbon sink strength. New Phytol 223:896-907. https:// doi.org/10.1111/nph.15806

Gentsch N, Wild B, Mikutta R, Čapek P, Diáková K, Schrumpf M, Turner S, Minnich C, Schaarschmidt F, Shibistova O, Schnecker J, Urich T, Gittel A, Šantrůčková H, Bárta J, Lashchinskiy N, Fuß R, Richter A, Guggenberger G (2018) Temperature response of permafrost soil carbon is attenuated by mineral protection. Glob Chang Biol 24:3401-3415. https://doi.org/10.1111/gcb.14316

Grimoldi AA, Kavanová M, Lattanzi FA, Schäufele R, Schnyder H (2006) Arbuscular mycorrhizal colonization on carbon economy in perennial ryegrass: quantification by $13 \mathrm{CO} 2 / 12 \mathrm{CO} 2$ steady-state labelling and gas exchange. New Phytol 172:544-553. https://doi. org/10.1111/j.1469-8137.2006.01853.x

Hewitt EJ (1966) Sand and water culture methods used in the study of plant nutrition, Technichal. University of Bristol Agricultural and Horticultural Research Station, Long Ashton, Bristol., East Malling, Maidstone, Kent

Hodge A (2017) Accessibility of inorganic and organic nutrients for mycorrhizas. In: Johnson NC, Gehring C, Jansa J (eds) Mycorrhizal mediation of soil: fertility, structure, and carbon storage. Elsevier, Amsterdam, pp 129-148

Holste EK, Kobe RK, Gehring CA (2016) Plant species differ in early seedling growth and tissue nutrient responses to arbuscular and ectomycorrhizal fungi. Mycorrhiza 27:211-223. https://doi.org/10. 1007/s00572-016-0744-x

IBM Corporation (2016) IBM SPSS statistics for windows, Version 24.0. 2016

Jansa J, Finlay RD, Wallander H, Smith FA, Smith SE (2011) Role of mycorrhizal symbioses in phosphorus cycling. In: Bunemann E, Oberson A, Frossard E (eds) Phosphorus in action. Biological Processes in soil phosphorus cycling. Springer, Netherlands, pp $137-168$

Johnson NC (2010) Resource stoichiometry elucidates the structure and function of arbuscular mycorrhizas across scales. New Phytol 185: 631-647. https://doi.org/10.1111/j.1469-8137.2009.03110.x

Johnson D, Leake JR, Ostle N, Ineson P, Read DJ, Leake JR, Ostle N, Ineson P, Johnson D, Leake JR, Ostle N, Ineson P, Read DJ (2002) In situ $13 \mathrm{CO} 2$ pulse-labelling of upland grassland demonstrates a rapid pathway of carbon flux from arbuscular mycorrhizal mycelia to the soil. New Phytol 153:327-334. https://doi.org/10.1046/j. 0028-646X.2001.00316.x

Johnston ER, Kim M, Hatt JK, Phillips JR, Yao Q, Song Y, Hazen TC, Mayes MA, Konstantinidis KT (2019) Phosphate addition increases tropical forest soil respiration primarily by deconstraining microbial population growth. Soil Biol Biochem 130:43-54. https://doi.org/ 10.1016/j.soilbio.2018.11.026

Kaiser C, Kilburn MR, Clode PL, Fuchslueger L, Koranda M, Cliff JB, Solaiman ZM, Murphy DV (2015) Exploring the transfer of recent plant photosynthates to soil microbes: mycorrhizal pathway vs direct root exudation. New Phytol 205:1537-1551. https://doi.org/10. 1111/nph.13138

Kim Y, Jordan D, McDonald GA (1998) Effect of phosphate-solubilizing bacteria and vesicular-arbuscular mycorrhizae on tomato growth 
and soil microbial activity. Biol Fertil Soils 26:79-87. https://oi. org/10.1007/s003740050347

Koele N, Dickie IA, Blum JD, Gleason JD, de Graaf L (2014) Ecological significance of mineral weathering in ectomycorrhizal and arbuscular mycorrhizal ecosystems from a field-based comparison. Soil Biol Biochem 69:63-70. https://doi.org/10.1016/j.soilbio.2013. 10.041

Köhl L, Lukasiewicz CE, Van der Heijden MGA (2016) Establishment and effectiveness of inoculated arbuscular mycorrhizal fungi in agricultural soils. Plant Cell Environ 39:136-146. https://doi.org/10. $1111 /$ pce. 12600

Koide RT, Kabir Z (2000) Extraradical hyphae of the mycorrhizal fungus Glomus intraradices can hydrolyse organic phosphate. New Phytol 148:511-517. https://doi.org/10.1046/j.1469-8137.2000.00776.x

Lambers H, Mougel C, Jaillard B, Hinsinger P (2009) Plant-microbe-soil interactions in the rhizosphere: an evolutionary perspective. Plant Soil 321:83-115. https://doi.org/10.1007/s11104-009-0042-x

Leake JR, Read DJ (2017) Mycorrhizal symbioses and pedogenesis throughout earth's history. In: Johnson NC, Gehring CA, Jansa J (eds) Mycorrhizal mediation of soil: fertility, structure, and carbon storage. Elsevier, Amsterdam, pp 9-33

Lecomte J, St-Arnaud M, Hijri M (2011) Isolation and identification of soil bacteria growing at the expense of arbuscular mycorrhizal fungi. FEMS Microbiol Lett 317:43-51. https://doi.org/10.1111/j.15746968.2011.02209.x

Li C, Kuyper TW, van der Werf W, Zhang J, Li H, Zhang F, Hoffland E (2019) Testing for complementarity in phosphorus resource use by mixtures of crop species. Plant Soil 439:163-177. https://doi.org/10. 1007/s11104-018-3732-4

Maathuis FJ (2009) Physiological functions of mineral macronutrients. Curr Opin Plant Biol 12:250-258. https://doi.org/10.1016/J.PBI. 2009.04.003

Mäder P, Vierheilig H, Alt M, Wiemken A (1993) Boundaries between soil compartments formed by microporous hydrophobic membranes (GORE-TEXR) can be crossed by vesicular-arbuscular mycorrizal fungi but not by ions in the soil solution. Plant Soil 152:201-206. https://doi.org/10.1007/BF00029089

Moyano FE, Kutsch WL, Schulze ED (2007) Response of mycorrhizal, rhizosphere and soil basal respiration to temperature and photosynthesis in a barley field. Soil Biol Biochem 39:843-853. https://doi. org/10.1016/j.soilbio.2006.10.001

Murdoch CL, Jackobs JA, Gerdemann JW (1967) Utilization of phosphorus sources of different availability by mycorrhizal and nonmycorrhizal maize. Plant Soil 27:329-334. https://doi.org/10.1007/ BF01376326

Ness RLLL, Vlek PLGG (2000) Mechanism of calcium and phosphate release from hydroxy-apatite by mycorrhizal hyphae. Soil Sci Soc Am J 64:949-955. https://doi.org/10.2136/sssaj2000.643949x

Nezat CA, Blum JD, Yanai RD, Park BB (2008) Mineral sources of calcium and phosphorus in soils of the northeastern United States. Soil Sci Soc Am J 72:1786-1794. https://doi.org/10.2136/ sssaj2007.0344

Nottingham AT, Turner BL, Winter K, van der Heijden MGA, Tanner EVJ (2010) Arbuscular mycorrhizal mycelial respiration in a moist tropical forest. New Phytol 186:957-967. https://doi.org/10.1111/j. 1469-8137.2010.03226.x

Olsson PA, Johansen A (2000) Lipid and fatty acid composition of hyphae and spores of arbuscular mycorrhizal fungi at different growth stages. Mycol Res 104:429-434. https://doi.org/10.1017/ S0953756299001410

Olsson PA, Johnson NC (2005) Tracking carbon from the atmosphere to the rhizosphere. Ecol Lett 8:1264-1270. https://doi.org/10.1111/j. 1461-0248.2005.00831.x

Osorio NW, Osorno L, Leon JD, Álvarez C (2017) Plant-microbe interactions for phosphate management in tropical soils. In: Naeem S,
Ansari AA, Gill S (eds) Essential plant nutrients. Springer, Cham, pp 491-512

Parádi I, Bratek Z, Láng F (2003) Influence of arbuscular mycorrhiza and phosphorus supply on polyamine content, growth and photosynthesis of Plantago lanceolata. Biol Plant 46:563-569. https://doi.org/10. 1023/A:1024819729317

Parniske M (2008) Arbuscular mycorrhiza: the mother of plant root endosymbioses. Nat Rev Microbiol 6:763-775

Pel R, Dupin S, Schat H, Ellers J, Kiers ET, van Straalen NM (2018) Growth benefits provided by different arbuscular mycorrhizal fungi to Plantago lanceolata depend on the form of available phosphorus. Eur J Soil Biol 88:89-96. https://doi.org/10.1016/j.ejsobi.2018.07. 004

Powell CL, Daniel J (1978) Mycorrhizal fungi stimulate uptake of soluble and insoluble phosphate fertilizer from a phosphate-deficient soil. New Phytol 80:351-358. https://doi.org/10.1111/j.1469-8137.1978. tb01568.x

Ptáček P (2016) Phosphate rocks. In: Ptáček P (ed) Apatites and their synthetic analogues - synthesis, structure, properties and applications. InTech, Brno University of Technology, Brno, pp 335-382

Püschel D, Bitterlich M, Rydlová J, Jansa J (2020) Facilitation of plant water uptake by an arbuscular mycorrhizal fungus: a Gordian knot of roots and hyphae. Mycorrhiza 30:299-313. https://doi.org/10. 1007/s00572-020-00949-9

Ramirez R, Mendoza B, Lizaso JI (2009) Mycorrhiza effect on maize P uptake from phosphate rock and superphosphate. Commun Soil Sci Plant Anal 40:2058-2071. https://doi.org/10.1080/ 00103620902960583

Raven JA, Lambers H, Smith SE, Westoby M, Raven JA, Lambers H, Smith SE, Westoby M (2018) Costs of acquiring phosphorus by vascular land plants: patterns and implications for plant coexistence. New Phytol 217:1420-1427. https://doi.org/10.1111/nph.14967

Rinnan R, Bååth E (2009) Differential utilization of carbon substrates by bacteria and fungi in tundra soil. Appl Environ Microbiol 75:36113620. https://doi.org/10.1128/AEM.02865-08

Rodríguez D, Keltjens WG, Goudriaan J (1998) Plant leaf area expansion and assimilate production in wheat (Triticum aestivum L.) growing under low phosphorus conditions. Plant Soil 200:227-240. https:// doi.org/10.1023/A:1004310217694

Sato T, Ezawa T, Cheng W, Tawaraya K (2015) Release of acid phosphatase from extraradical hyphae of arbuscular mycorrhizal fungus Rhizophagus clarus. Soil Sci Plant Nutr 61:269-274. https://doi.org/ 10.1080/00380768.2014.993298

Selvakumar G, Krishnamoorthy R, Kim K, Sa TM (2016) Genetic diversity and association characters of bacteria isolated from arbuscular mycorrhizal fungal spore walls. PLoS One 11:1-16. https://doi.org/ 10.1371/journal.pone.0160356

Shen J, Yuan L, Zhang J, Li H, Bai Z, Chen X, Zhang W, Zhang F, Jianbo S, Lixing Y, Zhang J, Haigang L, Bai Z, Chen X, Zhang W, Zhang F (2011) Phosphorus dynamics: from soil to plant. Plant Physiol 156: 997-1005. https://doi.org/10.1104/pp.111.175232

Slater C, Preston T, Weaver LT (2001) Stable isotopes and the international system of units. Rapid Commun Mass Spectrom 15:12701273. https://doi.org/10.1002/rcm.328

Smith SE, Read DJ (2008) Mycorrhizal symbiosis. Academic Press

Smits MM, Bonneville S, Benning LG, Banwart SA, Leake JR (2012) Plant-driven weathering of apatite - the role of an ectomycorrhizal fungus. Geobiology 10:445-456. https://doi.org/10.1111/j.14724669.2012.00331.x

Souchie EL, Azcón R, Barea JM, Silva EMRR, Saggin-Júnior OJ (2010) Enhancement of clover growth by inoculation of P-solubilizing fungi and arbuscular mycorrhizal fungi. An Acad Bras Cienc 82:771777. https://doi.org/10.1590/S0001-37652010000300023

Stumpe M, Carsjens J-GG, Stenzel I, Göbel C, Lang I, Pawlowski K, Hause B, Feussner I (2005) Lipid metabolism in arbuscular 
mycorrhizal roots of Medicago truncatula. Phytochemistry 66:781791. https://doi.org/10.1016/j.phytochem.2005.01.020

Taktek S, Trépanier M, Servin PM, St-Arnaud M, Piché Y, Fortin J-AA, Antoun H (2015) Trapping of phosphate solubilizing bacteria on hyphae of the arbuscular mycorrhizal fungus Rhizophagus irregularis DAOM 197198. Soil Biol Biochem 90:1-9. https://doi. org/10.1016/j.soilbio.2015.07.016

Taktek S, St-Arnaud M, Piché Y, Fortin JA, Antoun H (2017) Igneous phosphate rock solubilization by biofilm-forming mycorrhizobacteria and hyphobacteria associated with Rhizoglomus irregulare DAOM 197198. Mycorrhiza 27:13-22. https://doi.org/10.1007/s00572-016-0726-Z

Tisserant E, Kohler A, Dozolme-Seddas P, Balestrini R, Benabdellah K, Colard A, Croll D, da Silva C, Gomez SK, Koul R, Ferrol N, Fiorilli V, Formey D, Franken PH, Helber N, Hijri M, Lanfranco L, Lindquist E, Liu Y, Malbreil M, Morin E, Poulain J, Shapiro H, van Tuinen D, Waschke A, Azcón-Aguilar C, Bécard G, Bonfante P, Harrison MJ, Küster H, Lammers P, Paszkowski U, Requena N, Rensing SA, Roux C, Sanders IR, Shachar-Hill Y, Tuskan G, Young JPW, Gianinazzi-Pearson V, Martin F (2012) The transcriptome of the arbuscular mycorrhizal fungus Glomus intraradices (DAOM 197198) reveals functional tradeoffs in an obligate symbiont. New Phytol 193:755-769. https://doi.org/10.1111/j.1469-8137. 2011.03948.x

Tomè E, Ventura M, Folegot S, Zanotelli D, Montagnani L, Mimmo T, Tonon G, Tagliavini M, Scandellari F (2016) Mycorrhizal contribution to soil respiration in an apple orchard. Appl Soil Ecol 101:165173. https://doi.org/10.1016/j.apsoil.2016.01.016

Turner BL (2008) Resource partitioning for soil phosphorus: a hypothesis. J Ecol 96:698-702. https://doi.org/10.1111/j.1365-2745.2008. 01384.x

Van Aarle IM, Olsson PA (2003) Fungal lipid accumulation and development of mycelial structures by two arbuscular mycorrhizal. Appl Environ Microbiol 69:6762-6767. https://doi.org/10.1128/AEM. 69.11.6762

Veresoglou SD, Menexes G, Rillig MC (2012) Do arbuscular mycorrhizal fungi affect the allometric partition of host plant biomass to shoots and roots? A meta-analysis of studies from 1990 to 2010. Mycorrhiza 22:227-235. https://doi.org/10.1007/s00572-011-03987
Vermue E, Elbers J, Hoosbeek M (2008) A comparative field study of four soil respiration systems. http://edepot.wur.n1/120659. Accessed 25 Oct 2018

Vierheilig H, Coughlan AP, Wyss U, Piché Y (1998) Ink and vinegar, a simple staining technique for arbuscular-mycorrhizal fungi. Appl Environ Microbiol 64:5004-5007

Watkins NK, Fitter AH, Graves JD, Robinson D (1996) Carbon transfer between $\mathrm{C} 3$ and $\mathrm{C} 4$ plants linked by a common mycorrhizal network, quantified using stable carbon isotopes. Soil Biol Biochem 28:471-477. https://doi.org/10.1016/0038-0717(95)00189-1

Wewer V, Brands M, Dörmann P (2014) Fatty acid synthesis and lipid metabolism in the obligate biotrophic fungus Rhizophagus irregularis during mycorrhization of Lotus japonicus. Plant J 79: 398-412. https://doi.org/10.1111/tpj.12566

Willers C, Jansen van Rensburg PJ, Claassens S (2015) Phospholipid fatty acid profiling of microbial communities-a review of interpretations and recent applications. J Appl Microbiol 119:1207-1218. https://doi.org/10.1111/jam.12902

Wu Q-SS, Xia R-XX (2006) Arbuscular mycorrhizal fungi influence growth, osmotic adjustment and photosynthesis of citrus under well-watered and water stress conditions. J Plant Physiol 163:417425. https://doi.org/10.1016/j.jplph.2005.04.024

Zhang L, Xu M, Liu Y, Zhang F, Hodge A, Feng G (2016) Carbon and phosphorus exchange may enable cooperation between an arbuscular mycorrhizal fungus and a phosphate-solubilizing bacterium. New Phytol 210:1022-1032. https://doi.org/10.1111/nph. 13838

Zhang L, Feng G, Declerck S (2018) Signal beyond nutrient, fructose, exuded by an arbuscular mycorrhizal fungus triggers phytate mineralization by a phosphate solubilizing bacterium. ISME J 12:23392351. https://doi.org/10.1038/s41396-018-0171-4

Zou YN, Srivastava AK, Ni QD, Wu QS (2015) Disruption of mycorrhizal extraradical mycelium and changes in leaf water status and soil aggregate stability in rootbox-grown trifoliate orange. Front Microbiol 6. https://doi.org/10.3389/fmicb.2015.00203

Publisher's note Springer Nature remains neutral with regard to jurisdictional claims in published maps and institutional affiliations. 